Article

\title{
Design and Synthesis of Arylamidine Derivatives as Serotonin/Norepinephrine Dual Reuptake Inhibitors
}

\author{
Hui Wen ${ }^{1} \mathbb{D}$, Wen Qin ${ }^{2}$, Guangzhong Yang ${ }^{1}$ and Yanshen Guo ${ }^{1, *}$ \\ 1 Institute of Materia Medica, Chinese Academy of Medical Sciences \& Peking Union Medical College, \\ Beijing 100050, China; wenhui@imm.ac.cn (H.W.); chufm@imm.ac.cn (G.Y.) \\ 2 National Institute for Nutrition and Health, Chinese Center for Disease Control and Prevention, \\ Beijing 100050, China; qinwen@ninh.chinacdc.cn \\ * Correspondence: guoys@imm.ac.cn; Tel.: +86-10-63165249
}

Received: 15 January 2019; Accepted: 28 January 2019; Published: 30 January 2019

\begin{abstract}
To improve the in vivo antidepressant activity of previously reported serotonin (5-HT) and norepinephrine (NE) dual reuptake inhibitors, three series of arylamidine derivatives were designed and synthesized. The in vitro 5-HT and NE reuptake inhibitory activities of these compounds were evaluated, and compound II-5 was identified as the most potent 5-HT $\left(\mathrm{IC}_{50}=620 \mathrm{nM}\right)$ and NE $\left(\mathrm{IC}_{50}=10 \mathrm{nM}\right)$ dual reuptake inhibitor. Compound II-5 exhibited potent antidepressant activity in the rat tail suspension test and showed an acceptable safety profile in a preliminary acute toxicity test in mice. Our results show that these arylamidine derivatives exhibit potent 5-HT/NE dual reuptake inhibition and should be explored further as antidepressant drug candidates.
\end{abstract}

Keywords: serotonin; norepinephrine; dual reuptake inhibitors; antidepressant

\section{Introduction}

Depression is a common mental illness that can be severe, chronic, and sometimes life-threatening [1,2]. According to the World Health Organization, depression is one of the top causes of disability worldwide and affects 350 million people [3]. Therefore, there is an urgent need to develop antidepressants to improve the lives of people living with depression [4-7].

The biogenic amine transmitters, serotonin (5-HT), norepinephrine (NE), and dopamine (DA), are closely related to symptoms of depression [8]. First-generation antidepressants were mainly designed as single reuptake inhibitors, such as selective 5-HT reuptake inhibitors (SSRIs) and NE reuptake inhibitors (NRIs). Several single reuptake inhibitors, such as fluoxetine (SSRI) and reboxetine (NRI) (Figure 1), have poor safety and tolerability profiles. Second-generation antidepressants are dual reuptake inhibitors, such as 5-HT/NE reuptake inhibitors (SNRIs) and NE/DA reuptake inhibitors (NDRIs). Dual inhibitors currently on the market include bupropion (NDRI), venlafaxine (SNRI), and duloxetine (SNRI) (Figure 1). Dual reuptake inhibitors have better antidepressant effects and fewer side effects than single reuptake inhibitors [9]. SNRIs have a shorter working time and fewer adverse reactions, and thus are regarded as better antidepressant drugs than SSRIs [10].

In our previous study, we used compounds with 5-HT or NE reuptake inhibition activities to build a pharmacophore model of the characteristics of 5-HT and NE inhibitors (Figure 2) [11]. A series of substituted arylamidine derivatives was discovered using the 5-HT and NE pharmacophore model (Figure 3). One type of arylamidine derivative fitted the proposed 5-HT and NE pharmacophore model. Subsequent pharmacological tests indicated that these compounds showed good 5-HT and NE reuptake inhibition activity [12-14]. 
<smiles>CNCCC(Oc1ccc(C(F)(F)F)cc1)c1ccccc1</smiles>

Fluoxetine (SSRI)<smiles>CCOc1ccccc1OC(c1ccccc1)[C@H]1CNCCO1</smiles>

Reboxetine (NRI)<smiles>CC(NC(C)(C)C)C(=O)c1cccc(Cl)c1</smiles>

Bupropion (NDRI)<smiles>COc1ccc(C(CN(C)C)C2(O)CCCCC2)cc1</smiles>

Venlafaxine (SNRI)<smiles>CNCC[C@H](Oc1cccc2ccccc12)c1cccs1</smiles>

Duloxetine (SNRI)

Figure 1. Structures of antidepressants with single or dual reuptake inhibition.

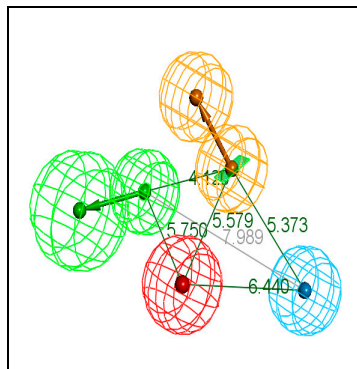

(a)

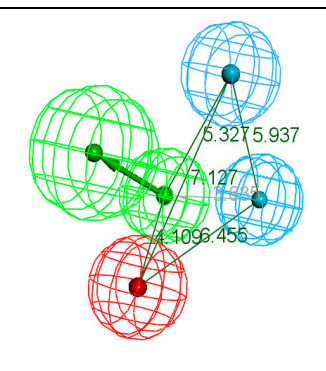

(b)

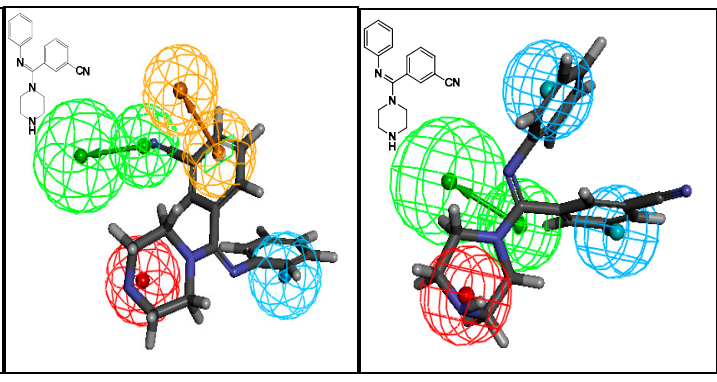

(c)

(d)

Figure 2. Proposed pharmacophore model Hypo1 of serotonin (5-HT) (a) and norepinephrine (NE) (b) produced by the Hypo Gen module in Catalyst 4.10 software (Accelrys, San Diego, CA, USA). The distance between the pharmacophore features is reported in angstroms. Mapping of an arylamidine derivative onto the 5-HT (c) and NE (d) pharmacophore models. Green, blue, brown, and red contours represent hydrogen-bond acceptor (HA), hydrophobic (HY), aromatic ring (RA), and positive ionizable (PI) pharmacophore features, respectively.

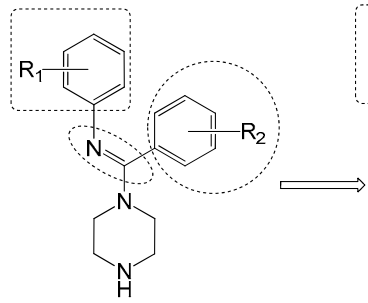

arylamidine derivatives

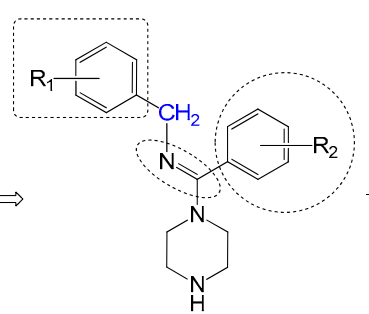

(E)-I

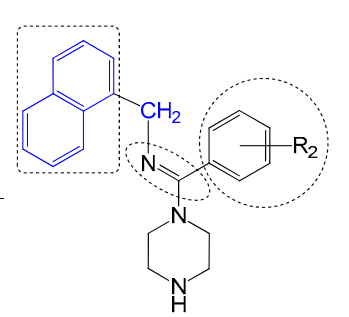

(E)-II

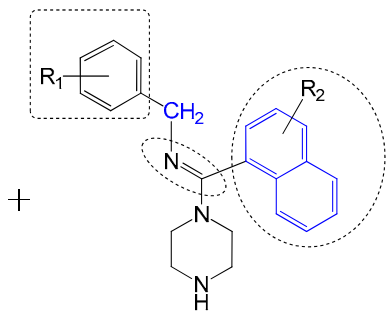

(E)-III

Figure 3. Design of inhibitor series I-III based on arylamidine derivatives.

However, an in vivo study of antidepressant activity in rats showed that arylamidine derivatives were less potent than the commercial SNRI antidepressants venlafaxine and duloxetine. We suspected that the high rigidity of the planar structure in arylamidine derivatives, compared with the structures of other SNRI inhibitors, such as venlafaxine and duloxetine, was a main cause of the poor antidepressant activity in rats. To circumvent these problems with arylamidine derivatives, in this work, we designed and synthesized 32 compounds in three series (I-III) of optimized arylamidine derivatives. The pharmacological activity of the 32 compounds was evaluated in vitro and selected compounds were evaluated in vivo. 


\section{Results and Discussion}

\subsection{Chemical Design and Modeling Prediction}

To increase the structural flexibility of the optimized compounds, we designed three series of compounds (Figure 3). A methylene group $\left(-\mathrm{CH}_{2}^{-}\right)$was inserted between the aromatic ring and nitrogen atom to form the structure of series I. Then, based on series I, another two series of derivatives were designed. In series II, the benzyl ring was replaced with a naphthalene ring and in series III, the amidine ring was replaced with a naphthalene ring.

The compounds were docked into the 5-HT and NE pharmacophore models, and all three types of molecules matched the model well. Compounds I-4 and II-4 are shown as examples of mapping on the pharmacophore model in Figure 4. Generally, the binding, as in the 5-HT and NE pharmacophore models, can be classified as aromatic ring (RA, brown), hydrophobic (HY, blue), positive ionizable (PI, red), and hydrogen-bond acceptor (HA, green) features. Compound I-4 was docked in the 5-HT model, and the two aromatic rings matched either the RA or HY features well. The nitrogen atoms of the piperazine ring were recognized as an HA feature, and the amidine imino nitrogen atom was recognized as a PI feature. Compound I-4 was also mapped on the NE model and the two aromatic rings matched the $\mathrm{HY}$ feature, the nitrogen atoms of the piperazine ring were recognized as the PI feature, and amidine imino nitrogen atom was recognized as the HA feature. We observed similar mapping for compound II-4 in both models.

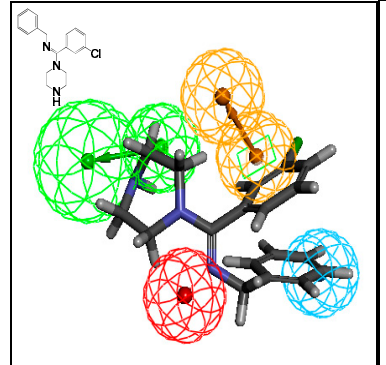

(a)

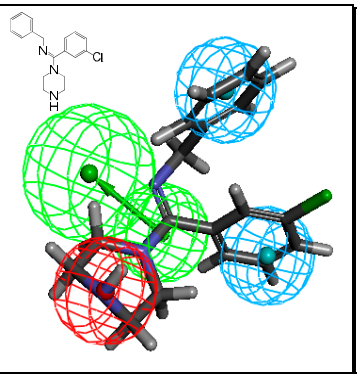

(b)

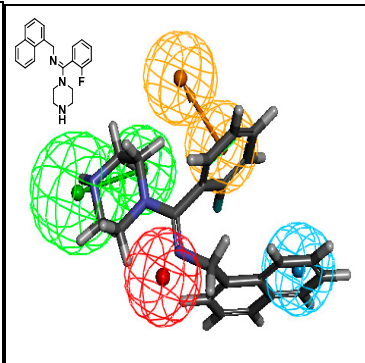

(c)

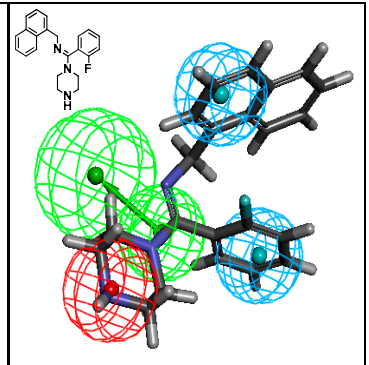

(d)

Figure 4. Mapping of compounds I-4 and II-4 on the serotonin (5-HT) pharmacophore model (a,c) and on the NE pharmacophore model $(\mathbf{b}, \mathbf{d})$. Green, blue, brown, and red contours represent hydrogen-bond acceptor (HA), hydrophobic (HY), aromatic ring (RA), and positive ionizable (PI) pharmacophore features, respectively.

Our experience suggested that for the design of a new series of compounds (Figure 2), the major pharmacodynamic domain in the arylamidine derivatives, including the $(E)$ configuration, would have to be retained. Only small changes to the structure of arylamidine derivatives are tolerated. Otherwise, the new compounds would lose their inhibitory activities against both 5-HT and NE reuptake. Thus, in the design, the key change was the addition of a methylene group, which broke the original planar configuration and increased the flexibility of the molecules. This design strategy balanced the pharmacological activity and the desired structural flexibility. Additionally, based on the pharmacophore models, the space for the aromatic ring in the arylamidine derivatives can tolerate a bigger aromatic fragment, such as an aphthalene ring. This might further favor the binding of the new compounds to either 5-HT or NE.

In summary, the docking study showed that all of the designed compounds matched the 5-HT and NE pharmacophore models well. The fragments in the compounds matched the corresponding binding domains in both models. Similar binding modes were observed for the mapping of compounds I-4 and II-4 in both models. The docking results indicated that the designed compounds were likely to be good dual reuptake inhibitors of 5-HT and NE. 


\subsection{Chemistry Synthesis}

The synthesis for series I-III is shown in Scheme 1. An aromatic acid (1) was used as the starting reagent to form an acyl chloride (2) with yields of 75-95\%. The intermediate (2) was reacted with various aromatic methylamines to form a substituted amide (3). The most important step in the scheme was the synthesis of compound 4 . All the final compounds had an $(E)$ configuration, which was initially formed in the production of acyl chloride 4 . (E)-acyl chloride 4 was obtained by the reaction between amide 3 and $\mathrm{PCl}_{5}$. During the synthesis of compound 5, piperazine could react with two molecules of compound 4 to produce disubstituted by-products. The amount of disubstituted by-products was reduced by increasing the amount of piperazine in this reaction. Subsequently, all target compounds were prepared as hydrochloride salts $(E)-\mathbf{I},(E)$-II, and $(E)$-III to obtain stable solids.

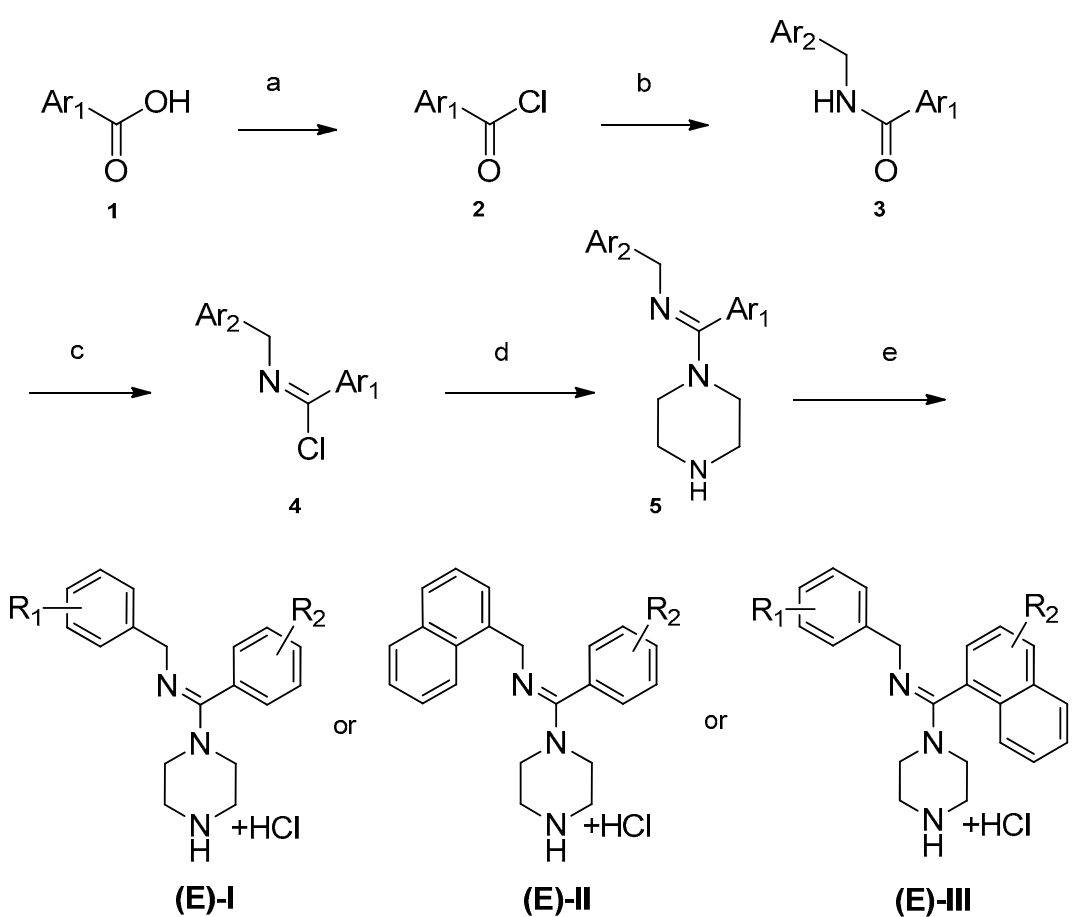

Scheme 1. Synthesis of (E)-I-(E)-III. (a) Oxalyl chloride, $\mathrm{CH}_{2} \mathrm{Cl}_{2}$; (b) $\mathrm{Ar}_{2}$-methylamine, triethylamine, $\mathrm{CH}_{2} \mathrm{Cl}_{2}$; (c) $\mathrm{PCl}_{5}, \mathrm{C}_{2} \mathrm{H}_{4} \mathrm{Cl}_{2}$; (d) piperazine, $\mathrm{CH}_{2} \mathrm{Cl}_{2}$; (e) ethanol, $\mathrm{HCl}$.

\subsection{Structure Confirmation}

1D-NOE NMR was used to confirm the configuration of the structure. The 1D-NOE spectrum of compound I-11 (Figure 5) showed weak NOE enhancements between the $\mathrm{H}_{\mathrm{a}}$ and $\mathrm{H}_{\mathrm{b}}$ protons, and $\mathrm{H}_{\mathrm{a}}$ and $\mathrm{H}_{\mathrm{c}}$ protons, indicating that the $\mathrm{H}_{\mathrm{a}}$ proton was spatially close to the $\mathrm{H}_{\mathrm{b}}$ and $\mathrm{H}_{\mathrm{c}}$ protons. Thus, the absolute configuration of the target compound was $(E)$.

In the ${ }^{1} \mathrm{H}-\mathrm{NMR}$ spectra of several compounds, such as I-15, the $\mathrm{Ar}-\mathrm{CH}_{2}-\mathrm{N}$ fragment exhibited a singlet, where as in the spectra of other compounds, such as I-14, the same fragment produced a double doublet. The only structural difference between I-14 and I-15 was the ortho- or para-chloro substituent on the amidine ring (Figure 6). The difference between the spectra may arise from the weak steric hindrance caused by the ortho-chloro substituent in I-14, but not by the para-chloro substituent in I-15. The steric hindrance would make the two protons in the $\mathrm{Ar}-\mathrm{CH}_{2}-\mathrm{N}$ fragment magnetically inequivalent in I-14, producing the double doublet. This observation is also important because if the configuration of the final compound was $(Z)$, and there would be no steric hindrance, the two $\mathrm{Ar}-\mathrm{CH}_{2}-\mathrm{N}$ protons would not be magnetically inequivalent, and the double doublet would not appear. Consequently, the steric hindrance indirectly indicated that the absolute configuration of the final compound was $(E)$. 

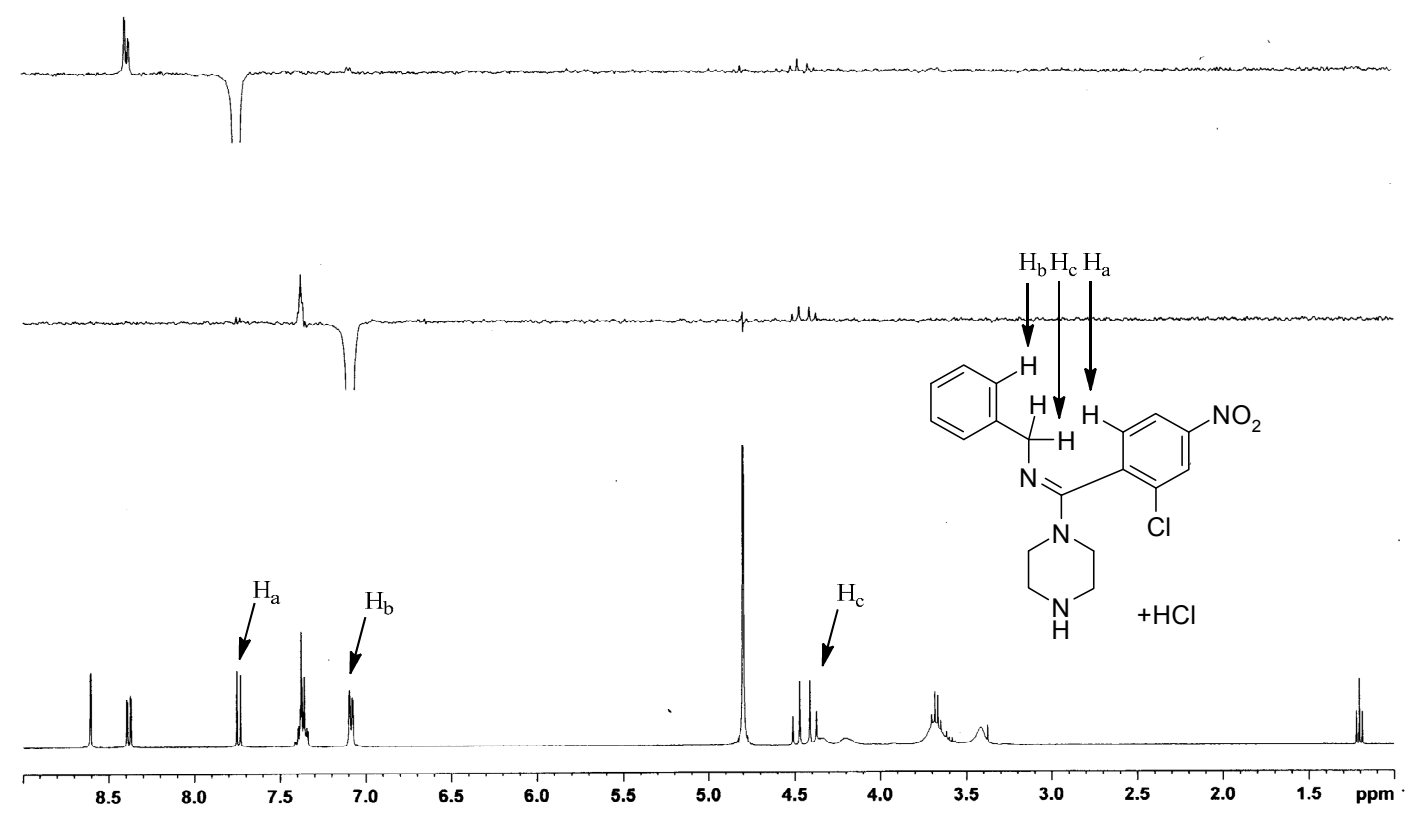

Figure 5. 1D-NOE NMR of compound (E)-I-11.

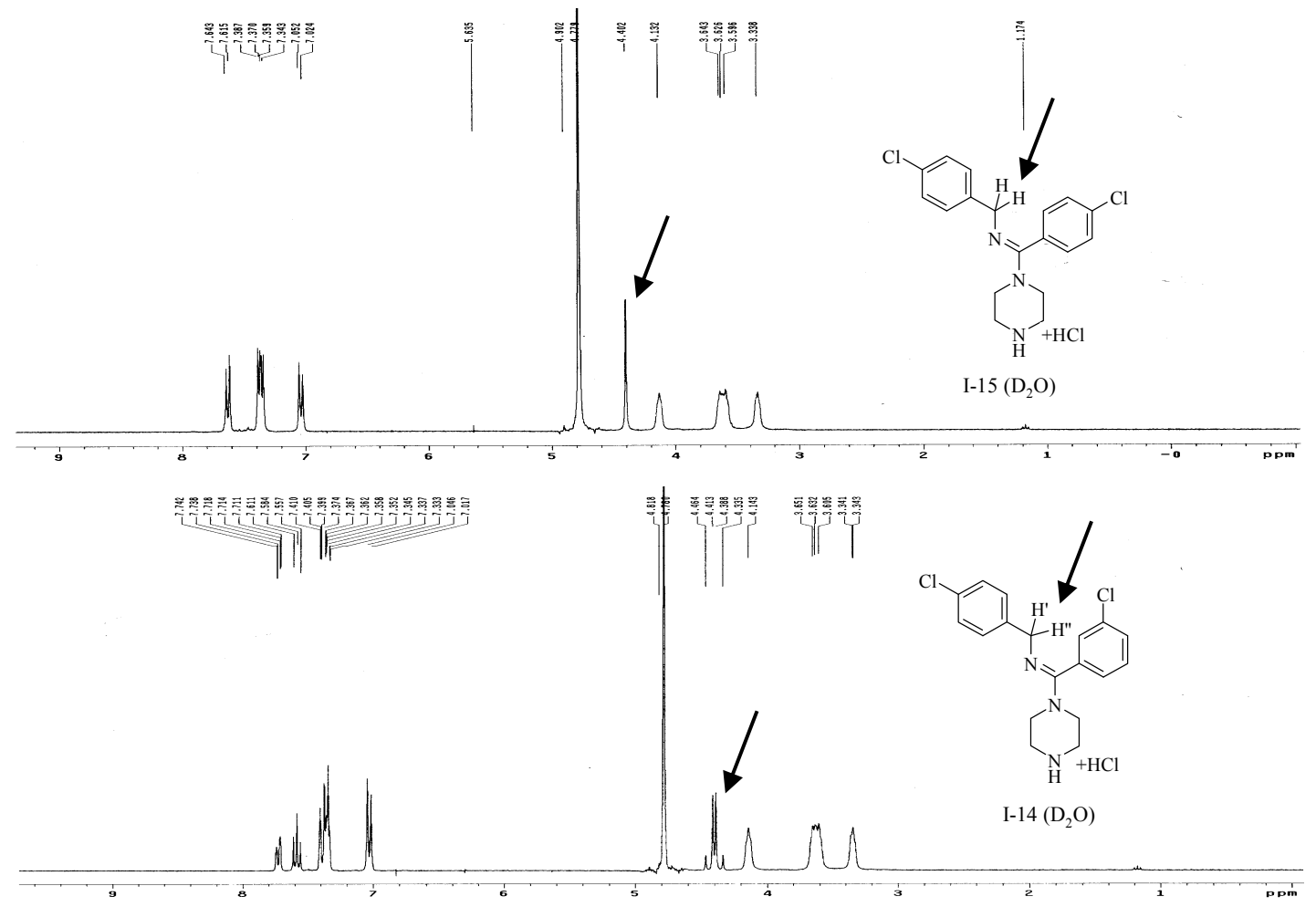

Figure 6. ${ }^{1} \mathrm{H}-\mathrm{NMR}$ spectra of I-14 and I-15.

\subsection{Biological Results and Discussion}

\subsubsection{In Vitro Test}

All the target compounds were evaluated for their inhibitory activity against the reuptake of 5-HT and NE at the cellular level. Rat brain tissue was used for the uptake test, which included ${ }^{3} \mathrm{H}-5-\mathrm{HT}$ and ${ }^{3} \mathrm{H}-\mathrm{NE}$ [15]. 1-[7,8- $\left.{ }^{3} \mathrm{H}\right]$-Noradrenaline and 5-hydroxy- $\left[{ }^{3} \mathrm{H}\right]$-tryptamine trifluoroacetate were obtained from Amersham Corporation. Duloxetine was used as the reference compound. All compounds were 
tested at a concentration of $10 \mu \mathrm{M}$, and potent compounds (inhibition $>80 \%$ ) were assayed to obtain $\mathrm{IC}_{50}$ values (Table 1$)$.

In series I, most compounds exhibited moderate dual reuptake inhibition activity. Compound I-19 was the most potent dual inhibitor in this series $\left(5-\mathrm{HT}, \mathrm{IC}_{50}=830 \mathrm{nM} ; \mathrm{NE}, \mathrm{IC}_{50}=560 \mathrm{nM}\right)$, and was comparable to the reference compound, duloxetine (5-HT, $\left.\mathrm{IC}_{50}=640 \mathrm{nM} ; \mathrm{NE}, \mathrm{IC}_{50}=49 \mathrm{nM}\right)$. In series II, compounds II-4 (5-HT, IC $50=130 \mathrm{nM}$; NE, IC $50=880 \mathrm{nM})$ and II-5 (5-HT, IC $50=620 \mathrm{nM}$; $\mathrm{NE}, \mathrm{IC}_{50}=10 \mathrm{nM}$ ) were the most potent compounds. Most compounds in this series had improved dual reuptake inhibition activity. In series III, compound III-1 also showed good potency for 5-HT and NE transporters.

The series I compounds maintained the dual 5-HT and NE inhibitory activity after the insertion of a methylene into the arylamidine derivative structure, although the general inhibitory activity was moderate. Various substituents on the benzene ring did not dramatically improve the binding of these compounds with the targets. In series II, a naphthalene ring replaced the benzyl ring. Interestingly, some compounds in this series exhibited dramatically improved dual inhibitory activities. Thus, the addition of a big hydrophobic fragment, that is, the naphthalene ring, improved binding to the5-HT and NE transporters.

Table 1. Inhibition data for serotonin (5-HT) and norephinephrine (NE) reuptake for series I III.

\begin{tabular}{|c|c|c|c|c|}
\hline Compd. & $\mathbf{R}_{1}$ & $\mathbf{R}_{\mathbf{2}}$ & $\begin{array}{l}5-\mathrm{HT}^{\mathrm{a}} \\
\left(\mathrm{IC}_{50}\right)^{\mathrm{b}}\end{array}$ & $\begin{array}{c}\mathrm{NE}^{\mathrm{a}} \\
\left(\mathrm{IC}_{50}\right)^{\mathrm{b}}\end{array}$ \\
\hline Duloxetine & - & - & $\begin{array}{c}86 \% \\
(640 \mathrm{nM})\end{array}$ & $\begin{array}{c}97 \% \\
(49 \mathrm{nM})\end{array}$ \\
\hline I-1 & $\mathrm{H}$ & $4-\mathrm{OCH}_{3}$ & $65 \%$ & $67 \%$ \\
\hline $\mathrm{I}-2$ & $\mathrm{H}$ & $4-\mathrm{NO}_{2}$ & $38 \%$ & $66 \%$ \\
\hline $\mathrm{I}-3$ & $\mathrm{H}$ & $2-\mathrm{Cl}$ & $48 \%$ & $65 \%$ \\
\hline I-4 & $\mathrm{H}$ & $3-\mathrm{Cl}$ & $58 \%$ & $63 \%$ \\
\hline $\mathrm{I}-5$ & $\mathrm{H}$ & $4-\mathrm{Cl}$ & $47 \%$ & $57 \%$ \\
\hline I-6 & $\mathrm{H}$ & $4-\mathrm{F}$ & $17 \%$ & $39 \%$ \\
\hline $\mathrm{I}-7$ & $\mathrm{H}$ & $2-\mathrm{F}$ & $38 \%$ & $35 \%$ \\
\hline I-8 & $\mathrm{H}$ & $4-\mathrm{CN}$ & $54 \%$ & $67 \%$ \\
\hline I-9 & $\mathrm{H}$ & $3-\mathrm{CN}$ & $65 \%$ & $51 \%$ \\
\hline I-10 & $\mathrm{H}$ & $4-\mathrm{CH}_{3}$ & $61 \%$ & $47 \%$ \\
\hline I-11 & $\mathrm{H}$ & $2-\mathrm{Cl}, 4-\mathrm{NO}_{2}$ & $50 \%$ & $49 \%$ \\
\hline I-12 & $4-\mathrm{Cl}$ & $4-\mathrm{NO}_{2}$ & $51 \%$ & $81 \%$ \\
\hline I-13 & $4-\mathrm{Cl}$ & $2-\mathrm{Cl}$ & $67 \%$ & $84 \%$ \\
\hline I-14 & $4-\mathrm{Cl}$ & $3-\mathrm{Cl}$ & $76 \%$ & $60 \%$ \\
\hline I-15 & $4-\mathrm{Cl}$ & $4-\mathrm{Cl}$ & $48 \%$ & $68 \%$ \\
\hline I-16 & $4-\mathrm{Cl}$ & $4-\mathrm{F}$ & $45 \%$ & $26 \%$ \\
\hline I-17 & $4-\mathrm{Cl}$ & $2-\mathrm{F}$ & $43 \%$ & $27 \%$ \\
\hline I-18 & $4-\mathrm{Cl}$ & $4-\mathrm{CN}$ & $75 \%$ & $63 \%$ \\
\hline I-19 & $4-\mathrm{Cl}$ & $3-\mathrm{CN}$ & $\begin{array}{c}82 \% \\
(830 \mathrm{nM})\end{array}$ & $\begin{array}{c}78 \% \\
(560 \mathrm{nM})\end{array}$ \\
\hline $\mathrm{I}-20$ & $4-\mathrm{Cl}$ & $4-\mathrm{CH}_{3}$ & $72 \%$ & $35 \%$ \\
\hline $\mathrm{I}-21$ & $4-\mathrm{OCH}_{3}$ & $4-\mathrm{NO}_{2}$ & $34 \%$ & $57 \%$ \\
\hline
\end{tabular}


Table 1. Cont

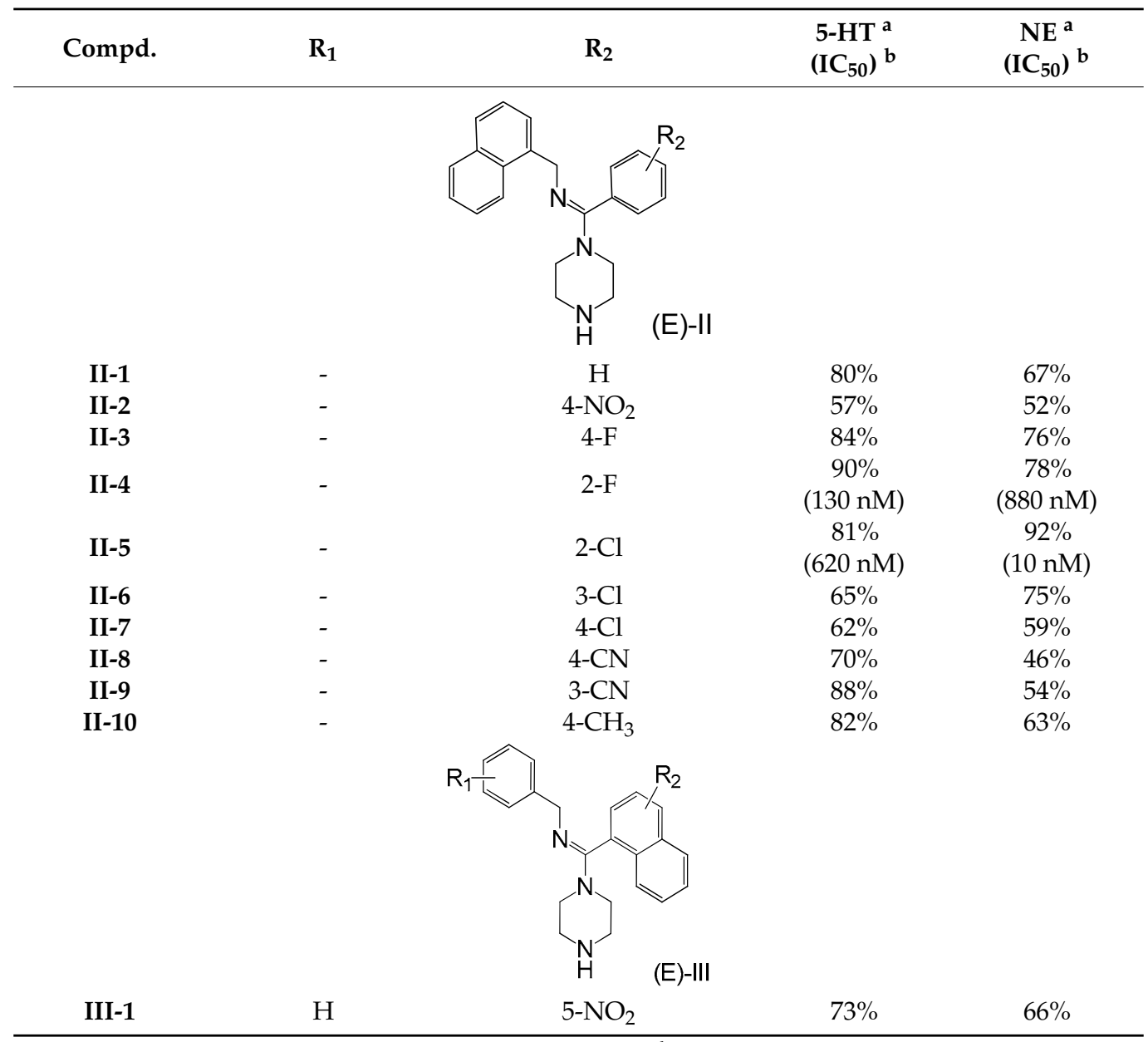

${ }^{a}$ Percent inhibition measured at a concentration of $10 \mu \mathrm{M},{ }^{b} \mathrm{IC}_{50}$ was tested for selected compounds.

\subsubsection{In Vivo Test}

Based on the in vitro results, compounds I-19, II-4, and II-5 were selected for the tail suspension test (TST) in rats. The TST has been used widely as a preclinical model for screening antidepressant activity, and it is sensitive to commercially available antidepressant drugs. In the assay, rats are suspended by tail and the time that the animal is immobile is recorded. The compounds were administered to male rats at a dose of $30 \mathrm{mg} / \mathrm{kg}$ (PO). Duloxetine was used as the positive control ( $30 \mathrm{mg} / \mathrm{kg}, \mathrm{PO}$ ). The compounds all reduced the immobility times of rats compared with the negative control vehicle group, indicating that all compounds exerted an antidepressant effect (Figure 7, Table 2). However, the antidepressant effect of compound II-5 was the closest to that of duloxetine, although it was still smaller. Both compound II-5 and duloxetine exhibited statistical significance for the antidepressant effect. In addition, the safety profile of compound II-5 was also explored with a preliminary acute toxicity test in mice at a single dose of 200 or $400 \mathrm{mg} / \mathrm{kg}(\mathrm{PO})(n=6)$. Compound II-5 did not result in the death of mice at doses of 200 and $400 \mathrm{mg} / \mathrm{kg}$ after $20 \mathrm{~h}$, and thus the $\mathrm{LD}_{50}$ was $>400 \mathrm{mg} / \mathrm{kg}$ (PO), indicating that the toxicity was low and that the safety profile was acceptable (Table 3).

In summary, compound II-5 had the most potent in vitro 5-HT and NE dual inhibitory activity of the three compounds used in the TST, and it also had the most potent in vivo pharmacological antidepressant effect. Compound II-5 was reasonably safe for mice at a dose of $30 \mathrm{mg} / \mathrm{kg}$. However, the in vivo antidepressant effect of compound II-5 (5-HT, IC $\left.\mathrm{I}_{50}=620 \mathrm{nM} ; \mathrm{NE}, \mathrm{IC}_{50}=10 \mathrm{nM}\right)$ was smaller than that of leading antidepressant duloxetine $\left(5-\mathrm{HT}, \mathrm{IC}_{50}=640 \mathrm{nM} ; \mathrm{NE}, \mathrm{IC}_{50}=49 \mathrm{nM}\right)$, although they 
had similar in vitro activities. The less potent in vivo antidepressant effect of compound II-5 may arise from its in vivo metabolism, which needs to be examined and optimized.

Table 2. The effect of four compounds in the rat test predictive of antidepressant activity.

\begin{tabular}{cccc}
\hline Group & Dose $\mathbf{( m g} / \mathbf{k g})$ & Immobility Time $\mathbf{( s )}$ & Rate of Shorten Time (\%) \\
\hline Vehicle & & $54 \pm 18$ & \\
Duloxetine & 30 & $11 \pm 5$ & 79.0 \\
I-19 & 30 & $34 \pm 17$ & 37.8 \\
II-4 & 30 & $33 \pm 19$ & 39.7 \\
II-5 & 30 & $18 \pm 7$ & 67.8 \\
\hline
\end{tabular}

Table 3. Acute toxicity of II-5 in mice.

\begin{tabular}{cccc}
\hline Dose $(\mathbf{m g} / \mathbf{k g})$ & Mice $(\boldsymbol{n})$ & Death $(\boldsymbol{n})$ & Survival at $\mathbf{2 0} \mathbf{~ h}$ \\
\hline 400 & 6 & 0 & $100 \%$ \\
200 & 6 & 0 & $100 \%$ \\
Vehicle & 6 & 0 & $100 \%$ \\
\hline
\end{tabular}

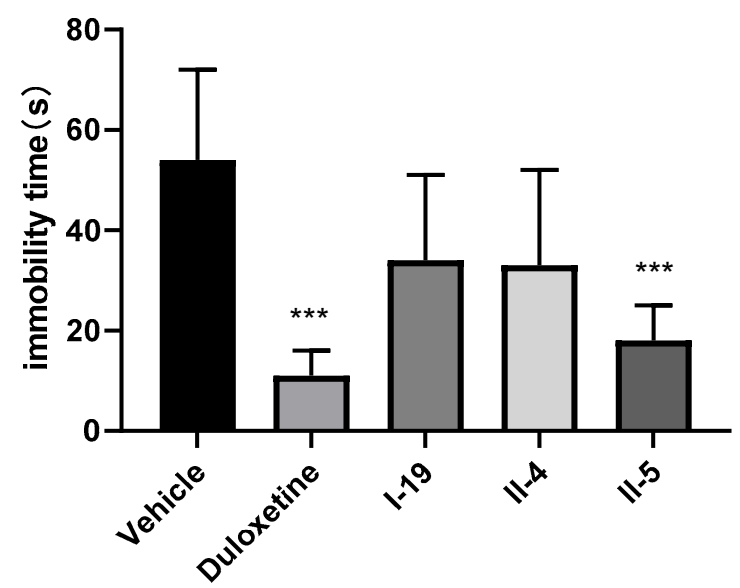

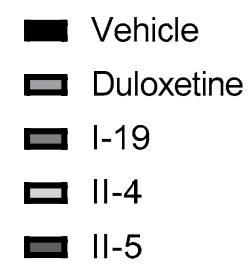

Figure 7. Tail suspension test (TST) results of compounds I-19, II-4, and II-5 and duloxetine (single dose of $30 \mathrm{mg} / \mathrm{kg}),\left({ }^{* * *} p<0.001\right)$.

\section{Experiment Section}

\subsection{Chemistry}

Most reagents and solvents were obtained from commercial suppliers and used as received. Some reactions were performed under an inert atmosphere $\left(\mathrm{N}_{2}\right)$. ${ }^{1} \mathrm{H}-\mathrm{NMR}$ spectra were obtained on an NMR spectrometer (Mercury, Varian, San Diego, CA, USA; 400MHz). Melting points were measured with a melting point apparatus (Yanaco-50, YANACO company, Kyoto, Japan) and are not corrected. Electro spray ionization (ESI) mass spectra and high-resolution mass spectroscopy (HRMS) were performed with a liquid chromatograph/mass selective detector time-of-flight mass spectrometer (LC/MSD TOF, Agilent Technologies, Santa Clara, CA, USA). The yields are of the purified product and are not optimized. Silica gel column chromatography was performed with silica gel 60G (Qingdao Haiyang Chemical, Qingdao, China). The procedure for preparing series I-III was the same as for compound I-1. Purity was determined using HPLC, LC/MS and NMR spectroscopy. All of the synthesized compounds have purity over $95 \%$. 
General Procedure for Preparing (E)-N-((4-Methoxyphenyl)(piperazin-1-yl)methylene)-1phenylmethanamine hydrochloride (I-1)

Preparation of N-Benzyl-4-methoxybenzamide

One drop of dry $N, N$-dimethyl formamide and oxalyl chloride $(0.62 \mathrm{~g}, 4.9 \mathrm{mmol})$ were added dropwise to a solution of 4-methoxybenzoic acid $(0.50 \mathrm{~g}$, $3.3 \mathrm{mmol})$ in dry $\mathrm{CH}_{2} \mathrm{Cl}_{2}(20 \mathrm{~mL})$. The reaction mixture was stirred at room temperature for $2 \mathrm{~h}$, and then distilled in vacuo to give the crude acyl chloride, which was dissolved in dry $\mathrm{CH}_{2} \mathrm{Cl}_{2}(10 \mathrm{~mL})$. Dry triethylamine $(0.40 \mathrm{~g}, 3.9 \mathrm{mmol})$ was added to a solution of benzylamine $(0.35 \mathrm{~g}, 3.3 \mathrm{mmol})$ in dry $\mathrm{CH}_{2} \mathrm{Cl}_{2}(20 \mathrm{~mL})$. The reaction mixture was cooled to $0{ }^{\circ} \mathrm{C}$, and the acyl chloride solution was added dropwise. After stirring at $20-25^{\circ} \mathrm{C}$ for $4 \mathrm{~h}$, the reaction mixture was distilled in vacuo, and washed with a $10 \%$ solution of $\mathrm{NaOH}$ and water, and dried. Silica gel column chromatography (hexane/ethyl acetate) afforded I-1 as a white powder ( $0.75 \mathrm{~g}, 94.8 \%$ yield).

Preparation of (E)-N-((4-Methoxyphenyl)(piperazin-1-yl)methylene)-1-phenylmethanamine hydrochloride (I-1)

$\mathrm{N}$-Benzyl-4-methoxybenzamide $(0.50 \mathrm{~g}, 2.1 \mathrm{mmol})$ was dissolved in dry dichloroethane $(10 \mathrm{~mL})$, and the solution was heated to $50{ }^{\circ} \mathrm{C}$ for $30 \mathrm{~min}$. $\mathrm{PCl}_{5}(0.44 \mathrm{~g}, 2.1 \mathrm{mmol})$ was added in one portion and the reaction was stirred at $90{ }^{\circ} \mathrm{C}$ for $2 \mathrm{~h}$. After most of the solvent was removed in vacuo, the residue was dissolved in dry $\mathrm{CH}_{2} \mathrm{Cl}_{2}(10 \mathrm{~mL})$ and was added dropwise to a solution of piperazine $(0.54 \mathrm{~g}$, $6 \mathrm{mmol})$ in dry $\mathrm{CH}_{2} \mathrm{Cl}_{2}(10 \mathrm{~mL})$ at $0{ }^{\circ} \mathrm{C}$. The reaction mixture was stirred at room temperature for $2 \mathrm{~h}$, and then distilled in vacuo. $\mathrm{Et}_{2} \mathrm{O}(50 \mathrm{~mL})$ and saturated aqueous $\mathrm{Na}_{2} \mathrm{CO}_{3}(30 \mathrm{~mL})$ were added to the mixture. After the aqueous extract was separated, the organic extract was washed twice with saturated aqueous $\mathrm{Na}_{2} \mathrm{CO}_{3}$ and $10 \%$ aqueous $\mathrm{NaOH}$, and then extracted with $1 \mathrm{~mol} / \mathrm{L} \mathrm{HCl}$. The aqueous extract was washed twice with $\mathrm{CH}_{2} \mathrm{Cl}_{2}$ and $\mathrm{Et}_{2} \mathrm{O}$, and was treated with $10 \%$ aqueous $\mathrm{NaOH}$ to increase the $\mathrm{pH}$ to 10. The aqueous extract was re-extracted with $\mathrm{Et}_{2} \mathrm{O}(50 \mathrm{~mL})$, and the $\mathrm{Et}_{2} \mathrm{O}$ extract was dried over $\mathrm{Na}_{2} \mathrm{SO}_{4}$. After $\mathrm{Et}_{2} \mathrm{O}$ was removed under vacuum, the residue was dissolved in dry ethanol $(5 \mathrm{~mL})$, and an ethanolic solution of $\mathrm{HCl}$ was added dropwise to adjust the $\mathrm{pH}$ to 2 to afford $\mathbf{I - 1}$ as a white powder (0.18 g, 25\% yield). Mp: 195-197 ${ }^{\circ} \mathrm{C} .{ }^{1} \mathrm{H}-\mathrm{NMR}\left(400 \mathrm{MHz}, \mathrm{D}_{2} \mathrm{O}\right): \delta 3.37$ (br, 2H, piperazinyl-H), 3.61 (br, 2H, piperazinyl-H), $3.66\left(\mathrm{br}, 2 \mathrm{H}\right.$, piperazinyl-H), $3.89\left(\mathrm{~s}, 3 \mathrm{H},-\mathrm{CH}_{3}\right), 4.13(\mathrm{br}, 2 \mathrm{H}$, piperazinyl-H), $4.44\left(\mathrm{~s}, 2 \mathrm{H},-\mathrm{CH}_{2}-\right), 7.10-7.16(\mathrm{~m}, 4 \mathrm{H}, \mathrm{ArH}), 7.35-7.41(\mathrm{~m}, 5 \mathrm{H}, \mathrm{ArH})$. HRMS calcd for $\mathrm{C}_{19} \mathrm{H}_{23} \mathrm{~N}_{3} \mathrm{O}$ $(\mathrm{M}+\mathrm{H})^{+}, 310.1914$; found, 310.1912 .

(E)-N-((4-Nitrophenyl)(piperazin-1-yl)methylene)-1-phenylmethanamine hydrochloride (I-2): Yield 40\%, Mp: 230-231 ${ }^{\circ} \mathrm{C} .{ }^{1} \mathrm{H}-\mathrm{NMR}\left(400 \mathrm{MHz}, \mathrm{D}_{2} \mathrm{O}\right): \delta 3.37$ (br, 2H, piperazinyl-H), 3.61 (br, 2H, piperazinyl-H), $3.66\left(\mathrm{br}, 2 \mathrm{H}\right.$, piperazinyl-H), $4.13\left(\mathrm{br}, 2 \mathrm{H}\right.$, piperazinyl-H), $4.44\left(\mathrm{~s}, 2 \mathrm{H},-\mathrm{CH}_{2}-\right), 7.10-7.16(\mathrm{~m}, 4 \mathrm{H}, \mathrm{ArH})$, 7.35-7.41 (m, 5H, ArH). HRMS calcd for $\mathrm{C}_{18} \mathrm{H}_{20} \mathrm{~N}_{4} \mathrm{O}_{2}(\mathrm{M}+\mathrm{H})^{+}$, 325.1659; found, 325.1654.

(E)-N-((2-Chlorophenyl)(piperazin-1-yl)methylene)-1-phenylmethanamine hydrochloride (I-3): Yield $18 \%$, Mp: 142-144 ${ }^{\circ} \mathrm{C} .{ }^{1} \mathrm{H}-\mathrm{NMR}\left(400 \mathrm{MHz}, \mathrm{D}_{2} \mathrm{O}\right): \delta 3.40$ (br, 2H, piperazinyl-H), 3.67 (br, $4 \mathrm{H}$, piperazinyl-H), $4.24\left(\mathrm{br}, 2 \mathrm{H}\right.$, piperazinyl-H), $4.38\left(\mathrm{~d}, 1 \mathrm{H}, J=14.0 \mathrm{~Hz},-\mathrm{CH}^{\prime}-\right), 4.46\left(\mathrm{~d}, 1 \mathrm{H}, J=14.0 \mathrm{~Hz},-\mathrm{CH}^{\prime \prime}-\right), 7.11-7.12(\mathrm{~m}$, 2H, ArH), 7.37-7.38 (m, 2H, ArH), $7.48(\mathrm{~d}, 1 \mathrm{H}, J=7.6 \mathrm{~Hz}, \mathrm{ArH}), 7.55-7.58(\mathrm{~m}, 2 \mathrm{H}, \mathrm{ArH}), 7.70-7.73(\mathrm{~m}$, $2 \mathrm{H}, \mathrm{ArH})$. HRMS calcd for $\mathrm{C}_{18} \mathrm{H}_{20} \mathrm{ClN}_{3}(\mathrm{M}+\mathrm{H})^{+}, 314.1419$; found, 314.1421 .

(E)-N-((3-Chlorophenyl)(piperazin-1-yl)methylene)-1-phenylmethanamine hydrochloride (I-4): Yield 66\%, Mp: 235-237 ${ }^{\circ} \mathrm{C} .{ }^{1} \mathrm{H}-\mathrm{NMR}\left(400 \mathrm{MHz}, \mathrm{D}_{2} \mathrm{O}\right): \delta 3.34(\mathrm{t}, 2 \mathrm{H}, J=5.4 \mathrm{~Hz}$, piperazinyl-H), 3.58-3.66 (m, 4H, piperazinyl-H), $4.14\left(\mathrm{t}, 2 \mathrm{H}, J=5.4 \mathrm{~Hz}\right.$, piperazinyl-H), $4.39\left(\mathrm{~d}, 1 \mathrm{H}, J=15.9 \mathrm{~Hz},-\mathrm{CH}^{\prime}-\right), 4.45(\mathrm{~d}, 1 \mathrm{H}$, $\left.J=15.9 \mathrm{~Hz},-\mathrm{CH}^{\prime \prime}-\right), 7.07-7.11(\mathrm{~m}, 2 \mathrm{H}, \mathrm{ArH}), 7.35-7.38(\mathrm{~m}, 4 \mathrm{H}, \mathrm{ArH}), 7.45(\mathrm{~s}, 1 \mathrm{H}, \mathrm{ArH}), 7.56-7.61(\mathrm{~m}, 1 \mathrm{H}$, $\mathrm{ArH}), 7.73\left(\mathrm{~d}, 1 \mathrm{H}, J=7.2 \mathrm{~Hz}\right.$, ArH). HRMS calcd for $\mathrm{C}_{18} \mathrm{H}_{20} \mathrm{ClN}_{3}(\mathrm{M}+\mathrm{H})^{+}, 314.1419$; found, 314.1411. 
(E)-N-((4-Chlorophenyl)(piperazin-1-yl)methylene)-1-phenylmethanamine hydrochloride (I-5): Yield 65\%, Mp: 182-184 ${ }^{\circ} \mathrm{C} .{ }^{1} \mathrm{H}-\mathrm{NMR}\left(400 \mathrm{MHz}, \mathrm{D}_{2} \mathrm{O}\right): \delta 3.35$ (br, $2 \mathrm{H}$, piperazinyl-H), $3.64(\mathrm{br}, 4 \mathrm{H}$, piperazinyl-H), $4.14\left(\mathrm{br}, 2 \mathrm{H}\right.$, piperazinyl-H), $4.42\left(\mathrm{~s}, 2 \mathrm{H},-\mathrm{CH}_{2}-\right), 7.11(\mathrm{br}, 2 \mathrm{H}, \mathrm{ArH}), 7.35-7.42(\mathrm{~m}, 5 \mathrm{H}, \mathrm{ArH}), 7.63(\mathrm{~d}, 2 \mathrm{H}$, $J=8.4 \mathrm{~Hz}, \mathrm{ArH})$. HRMS calcd for $\mathrm{C}_{18} \mathrm{H}_{20} \mathrm{ClN}_{3}(\mathrm{M}+\mathrm{H})^{+}, 314.1419$; found, 314.1414.

(E)-N-((4-Fluorophenyl)(piperazin-1-yl)methylene)-1-phenylmethanamine hydrochloride (I-6): Yield 33\%, Mp: 220-222 ${ }^{\circ} \mathrm{C} .{ }^{1} \mathrm{H}-\mathrm{NMR}\left(400 \mathrm{MHz}, \mathrm{D}_{2} \mathrm{O}\right): \delta 3.34(\mathrm{br}, 2 \mathrm{H}$, piperazinyl-H), $3.58(\mathrm{br}, 2 \mathrm{H}$, piperazinyl-H), $3.64\left(\mathrm{br}, 2 \mathrm{H}\right.$, piperazinyl-H), $4.12\left(\mathrm{br}, 2 \mathrm{H}\right.$, piperazinyl-H), $4.43\left(\mathrm{~s}, 2 \mathrm{H},-\mathrm{CH}_{2}-\right), 7.11(\mathrm{br}, 2 \mathrm{H}, \mathrm{ArH})$, 7.32-7.37 (m, 5H, ArH), 7.46-7.50 (m, 2H, ArH). HRMS calcd for $\mathrm{C}_{18} \mathrm{H}_{20} \mathrm{FN}_{3}(\mathrm{M}+\mathrm{H})^{+}$, 298.1714; found, 298.1710 .

(E)-N-((2-Fluorophenyl)(piperazin-1-yl)methylene)-1-phenylmethanamine hydrochloride (I-7): Yield 22\%, Mp: 182-184 ${ }^{\circ} \mathrm{C} .{ }^{1} \mathrm{H}-\mathrm{NMR}\left(400 \mathrm{MHz}, \mathrm{D}_{2} \mathrm{O}\right): \delta 3.34$ (br, 2H, piperazinyl-H), 3.59 (br, $2 \mathrm{H}$, piperazinyl-H), $3.71\left(\mathrm{br}, 2 \mathrm{H}\right.$, piperazinyl-H), $4.17\left(\mathrm{br}, 2 \mathrm{H}\right.$, piperazinyl-H), $4.42\left(\mathrm{~d}, 1 \mathrm{H}, J=15.6 \mathrm{~Hz},-\mathrm{CH}^{\prime \prime}-\right), 4.49$ (d, $\left.1 \mathrm{H}, J=15.6 \mathrm{~Hz},-\mathrm{CH}^{\prime \prime}-\right), 7.08-7.10(\mathrm{~m}, 2 \mathrm{H}, \mathrm{ArH}), 7.34-7.39(\mathrm{~m}, 4 \mathrm{H}, \mathrm{ArH}), 7.43-7.45(\mathrm{~m}, 2 \mathrm{H}, \mathrm{ArH})$, 7.72-7.80 (m, 1H, ArH). HRMS calcd for $\mathrm{C}_{18} \mathrm{H}_{20} \mathrm{FN}_{3}(\mathrm{M}+\mathrm{H})^{+}$, 298.1714; found, 298.1706.

(E)-4-((Benzylimino)(piperazin-1-yl)methyl)benzonitrile hydrochloride (I-8): Yield 38\%, Mp: 205-207 ${ }^{\circ} \mathrm{C}$. ${ }^{1} \mathrm{H}-\mathrm{NMR}\left(400 \mathrm{MHz}, \mathrm{D}_{2} \mathrm{O}\right): \delta 3.36(\mathrm{br}, 2 \mathrm{H}$, piperazinyl-H), $3.61(\mathrm{br}, 4 \mathrm{H}$, piperazinyl-H), $4.17(\mathrm{br}, 2 \mathrm{H}$, piperazinyl-H), $4.40\left(\mathrm{~s}, 2 \mathrm{H},-\mathrm{CH}_{2}-\right), 7.04-7.08(\mathrm{~m}, 2 \mathrm{H}, \mathrm{ArH}), 7.34-7.36(\mathrm{~m}, 3 \mathrm{H}, \mathrm{ArH}), 7.60(\mathrm{~d}, 2 \mathrm{H}$, $J=8.4 \mathrm{~Hz}, \mathrm{ArH}), 7.98(\mathrm{~d}, 2 \mathrm{H}, J=8.4 \mathrm{~Hz}, \mathrm{ArH})$. HRMS calcd for $\mathrm{C}_{19} \mathrm{H}_{20} \mathrm{~N}_{4}(\mathrm{M}+\mathrm{H})^{+}$, 305.1761; found, 305.1760 .

(E)-3-((Benzylimino)(piperazin-1-yl)methyl)benzonitrile hydrochloride (I-9): Yield 60\%, Mp: 190-192 ${ }^{\circ} \mathrm{C}$. ${ }^{1} \mathrm{H}-\mathrm{NMR}\left(400 \mathrm{MHz}, \mathrm{D}_{2} \mathrm{O}\right): \delta 3.35(\mathrm{br}, 2 \mathrm{H}$, piperazinyl-H), $3.61(\mathrm{br}, 4 \mathrm{H}$, piperazinyl-H), $4.18(\mathrm{br}, 2 \mathrm{H}$, piperazinyl-H), $4.36\left(\mathrm{~d}, 1 \mathrm{H}, J=15.6 \mathrm{~Hz},-\mathrm{CH}^{\prime}-\right), 4.44\left(\mathrm{~d}, 1 \mathrm{H}, J=15.6 \mathrm{~Hz},-\mathrm{CH}^{\prime \prime}-\right), 7.04-7.06(\mathrm{~m}, 2 \mathrm{H}$, ArH), 7.31-7.41 (m, 3H, ArH), 7.72-7.81 (m, 3H, ArH), 8.07 (d, 1H, J = 6.9 Hz, ArH). HRMS calcd for $\mathrm{C}_{19} \mathrm{H}_{20} \mathrm{~N}_{4}(\mathrm{M}+\mathrm{H})^{+}$, 305.1761; found, 305.1758 .

(E)-1-Phenyl-N-(piperazin-1-yl(p-tolyl)methylene)methanamine hydrochloride (I-10): Yield 50\%, Mp: 172-174 ${ }^{\circ} \mathrm{C} .{ }^{1} \mathrm{H}-\mathrm{NMR}\left(400 \mathrm{MHz}, \mathrm{D}_{2} \mathrm{O}\right): \delta 2.42\left(\mathrm{~s}, 3 \mathrm{H},-\mathrm{CH}_{3}\right), 3.34(\mathrm{t}, 2 \mathrm{H}, J=5.4 \mathrm{~Hz}, J=5.1 \mathrm{~Hz}$, piperazinyl- $\mathrm{H}), 3.59(\mathrm{t}, 2 \mathrm{H}, J=5.7 \mathrm{~Hz}, J=5.1 \mathrm{~Hz}$, piperazinyl- $\mathrm{H}), 3.64(\mathrm{t}, 2 \mathrm{H}, J=5.7 \mathrm{~Hz}$, piperazinyl-H), $4.12\left(\mathrm{t}, 2 \mathrm{H}, J=6.0 \mathrm{~Hz}\right.$, piperazinyl-H), $4.42\left(\mathrm{~s}, 2 \mathrm{H},-\mathrm{CH}_{2}-\right), 7.09-7.12(\mathrm{~m}, 2 \mathrm{H}, \mathrm{ArH}), 7.30-7.37(\mathrm{~m}, 5 \mathrm{H}$, ArH), $7.45\left(\mathrm{~d}, 2 \mathrm{H}, J=8.1 \mathrm{~Hz}\right.$, ArH). HRMS calcd for $\mathrm{C}_{19} \mathrm{H}_{23} \mathrm{~N}_{3}(\mathrm{M}+\mathrm{H})^{+}, 294.1965$; found, 294.1962.

(E)-N-((2-Chloro-4-nitrophenyl)(piperazin-1-yl)methylene)-1-phenylmethanamine hydrochloride (I-11): Yield 73\%, Mp: $195-197{ }^{\circ} \mathrm{C} .{ }^{1} \mathrm{H}-\mathrm{NMR}\left(400 \mathrm{MHz}, \mathrm{D}_{2} \mathrm{O}\right): \delta 3.39$ (br, 2H, piperazinyl-H), 3.66 (br, 4H, piperazinyl-H), $4.13\left(\mathrm{br}, 2 \mathrm{H}\right.$, piperazinyl-H), $4.35\left(\mathrm{~d}, 1 \mathrm{H}, J=15.6 \mathrm{~Hz},-\mathrm{CH}^{\prime}-\right), 4.46(\mathrm{~d}, 1 \mathrm{H}, J=15.6 \mathrm{~Hz}$, $\left.-\mathrm{CH}^{\prime \prime}-\right), 7.05(\mathrm{~d}, 2 \mathrm{H}, J=7.8 \mathrm{~Hz}, \mathrm{ArH}), 7.31-7.38(\mathrm{~m}, 3 \mathrm{H}, \mathrm{ArH}), 7.71(\mathrm{~d}, 1 \mathrm{H}, J=8.7 \mathrm{~Hz}, \mathrm{ArH}), 8.35(\mathrm{~d}, 1 \mathrm{H}$, $J=8.4 \mathrm{~Hz}, \mathrm{ArH}), 8.57(\mathrm{~s}, 1 \mathrm{H}, J=8.7 \mathrm{~Hz}, \mathrm{ArH})$. HRMS calcd for $\mathrm{C}_{18} \mathrm{H}_{19} \mathrm{ClN}_{4} \mathrm{O}_{2}(\mathrm{M}+\mathrm{H})^{+}, 359.1269$; found, 359.1277 .

(E)-1-(4-Chlorophenyl)-N-((4-nitrophenyl)(piperazin-1-yl)methylene)methanamine hydrochloride (I-12): Yield 22\%, Mp: $172-174{ }^{\circ} \mathrm{C} .{ }^{1} \mathrm{H}-\mathrm{NMR}\left(400 \mathrm{MHz}, \mathrm{D}_{2} \mathrm{O}\right): \delta 3.35$ (br, 2H, piperazinyl-H), $3.65(\mathrm{br}, 4 \mathrm{H}$, piperazinyl-H), $4.18\left(\mathrm{br}, 2 \mathrm{H}\right.$, piperazinyl-H), $4.39\left(\mathrm{~s}, 2 \mathrm{H},-\mathrm{CH}_{2}-\right), 7.01(\mathrm{~d}, 2 \mathrm{H}, J=8.4 \mathrm{~Hz}, \mathrm{ArH}), 7.34(\mathrm{~d}$, $2 \mathrm{H}, J=8.4 \mathrm{~Hz}, \mathrm{ArH}), 7.67(\mathrm{~d}, 2 \mathrm{H}, J=8.7 \mathrm{~Hz}, \mathrm{ArH}), 8.42(\mathrm{~d}, 2 \mathrm{H}, J=8.7 \mathrm{~Hz}, \mathrm{ArH})$. HRMS calcd for $\mathrm{C}_{18} \mathrm{H}_{19} \mathrm{ClN}_{4} \mathrm{O}_{2}(\mathrm{M}+\mathrm{H})^{+}, 359.1269$; found, 359.1271 .

(E)-1-(4-Chlorophenyl)-N-((2-chlorophenyl)(piperazin-1-yl)methylene)methanamine hydrochloride (I-13): Yield 56\%, Mp: 181-183 ${ }^{\circ} \mathrm{C} .{ }^{1} \mathrm{H}-\mathrm{NMR}\left(400 \mathrm{MHz}, \mathrm{D}_{2} \mathrm{O}\right): \delta 3.36$ (br, $2 \mathrm{H}$, piperazinyl-H), 3.61 (br, $4 \mathrm{H}$, piperazinyl-H), $4.14\left(\mathrm{br}, 2 \mathrm{H}\right.$, piperazinyl-H), $4.34\left(\mathrm{~d}, 1 \mathrm{H}, J=15.6 \mathrm{~Hz},-\mathrm{CH}^{\prime}-\right), 4.42(\mathrm{~d}, 1 \mathrm{H}, J=15.6 \mathrm{~Hz}$, 
$\left.-\mathrm{CH}^{\prime \prime}-\right), 7.01(\mathrm{~d}, 2 \mathrm{H}, J=8.4 \mathrm{~Hz}, \mathrm{ArH}), 7.33(\mathrm{~d}, 2 \mathrm{H}, J=8.4 \mathrm{~Hz}, \mathrm{ArH}), 7.42(\mathrm{~d}, 1 \mathrm{H}, J=7.8 \mathrm{~Hz}, \mathrm{ArH}), 7.55(\mathrm{t}$, $1 \mathrm{H}, J=7.5 \mathrm{~Hz}, \mathrm{ArH}), 7.64-7.72(\mathrm{~m}, 2 \mathrm{H}, \mathrm{ArH})$. HRMS calcd for $\mathrm{C}_{18} \mathrm{H}_{19} \mathrm{Cl}_{2} \mathrm{~N}_{3}(\mathrm{M}+\mathrm{H})^{+}, 348.1029$; found, 348.1032 .

(E)-1-(4-Chlorophenyl)-N-((3-chlorophenyl)(piperazin-1-yl)methylene)methanamine hydrochloride (I-14): Yield 53\%, Mp: $218-220{ }^{\circ} \mathrm{C} .{ }^{1} \mathrm{H}-\mathrm{NMR}\left(400 \mathrm{MHz}, \mathrm{D}_{2} \mathrm{O}\right): \delta 3.34(\mathrm{br}, 2 \mathrm{H}$, piperazinyl-H), $3.63(\mathrm{br}, 4 \mathrm{H}$, piperazinyl-H), $4.14(\mathrm{br}, 2 \mathrm{H}$, piperazinyl- $\mathrm{H}), 4.35\left(\mathrm{~d}, 1 \mathrm{H}, J=15.9 \mathrm{~Hz},-\mathrm{CH}^{\prime}-\right), 4.35(\mathrm{~d}, 1 \mathrm{H}, J=15.9 \mathrm{~Hz}$, $\left.-\mathrm{CH}^{\prime \prime}-\right), 7.03(\mathrm{~d}, 2 \mathrm{H}, J=8.7 \mathrm{~Hz}, \mathrm{ArH}), 7.33-7.37(\mathrm{~m}, 3 \mathrm{H}, \mathrm{ArH}), 7.40(\mathrm{~s}, 1 \mathrm{H}, \mathrm{ArH}), 7.55-7.61(\mathrm{~m}, 1 \mathrm{H}, \mathrm{ArH})$, $7.72(\mathrm{~d}, 1 \mathrm{H}, J=7.2 \mathrm{~Hz}, \mathrm{ArH})$. HRMS calcd for $\mathrm{C}_{18} \mathrm{H}_{19} \mathrm{Cl}_{2} \mathrm{~N}_{3}(\mathrm{M}+\mathrm{H})^{+}$, 348.1029; found, 348.1027.

(E)-1-(4-Chlorophenyl)-N-((4-chlorophenyl)(piperazin-1-yl)methylene)methanamine hydrochloride (I-15): Yield 36\%, Mp: $157-159{ }^{\circ} \mathrm{C} .{ }^{1} \mathrm{H}-\mathrm{NMR}\left(400 \mathrm{MHz}, \mathrm{D}_{2} \mathrm{O}\right): \delta 3.33(\mathrm{br}, 2 \mathrm{H}$, piperazinyl-H), $3.62(\mathrm{br}, 4 \mathrm{H}$, piperazinyl-H), $4.13\left(\mathrm{br}, 2 \mathrm{H}\right.$, piperazinyl-H), $4.40\left(\mathrm{~s}, 2 \mathrm{H},-\mathrm{CH}_{2}-\right), 7.03(\mathrm{~d}, 2 \mathrm{H}, J=8.4 \mathrm{~Hz}, \mathrm{ArH}), 7.35(\mathrm{~d}$, $2 \mathrm{H}, J=8.1 \mathrm{~Hz}, \mathrm{ArH}), 7.37(\mathrm{~d}, 2 \mathrm{H}, J=8.1 \mathrm{~Hz}, \mathrm{ArH}), 7.63(\mathrm{~d}, 2 \mathrm{H}, J=8.4 \mathrm{~Hz}, \mathrm{ArH})$. HRMS calcd for $\mathrm{C}_{18} \mathrm{H}_{19} \mathrm{Cl}_{2} \mathrm{~N}_{3}(\mathrm{M}+\mathrm{H})^{+}$, 348.1029; found, 348.1027.

(E)-1-(4-Chlorophenyl)-N-((4-fluorophenyl)(piperazin-1-yl)methylene)methanamine hydrochloride (I-16): Yield 20\%, Mp: $165-167{ }^{\circ} \mathrm{C} .{ }^{1} \mathrm{H}-\mathrm{NMR}\left(400 \mathrm{MHz}, \mathrm{D}_{2} \mathrm{O}\right): \delta 3.34(\mathrm{br}, 2 \mathrm{H}$, piperazinyl-H), $3.62(\mathrm{br}$, $4 \mathrm{H}$, piperazinyl-H), $4.13\left(\mathrm{br}, 2 \mathrm{H}\right.$, piperazinyl-H), $4.41\left(\mathrm{~s}, 2 \mathrm{H},-\mathrm{CH}_{2}-\right), 7.05(\mathrm{~d}, 2 \mathrm{H}, J=8.1 \mathrm{~Hz}, \mathrm{ArH})$, 7.31-7.37 (m, 4H, ArH), 7.42-7.47 (m, 2H, ArH). HRMS calcd for $\mathrm{C}_{18} \mathrm{H}_{19} \mathrm{ClFN}_{3}(\mathrm{M}+\mathrm{H})^{+}, 332.1324$; found, 332.1323 .

(E)-1-(4-Chlorophenyl)-N-((2-fluorophenyl)(piperazin-1-yl)methylene)methanamine hydrochloride (I-17): Yield $21 \%$, Mp: $215-217^{\circ} \mathrm{C} .{ }^{1} \mathrm{H}-\mathrm{NMR}\left(400 \mathrm{MHz}, \mathrm{D}_{2} \mathrm{O}\right): \delta 3.26(\mathrm{br}, 2 \mathrm{H}$, piperazinyl-H), $3.52(\mathrm{br}, 2 \mathrm{H}$, piperazinyl-H), $3.70\left(\mathrm{br}, 2 \mathrm{H}\right.$, piperazinyl-H), $4.18(\mathrm{br}, 2 \mathrm{H}$, piperazinyl- $\mathrm{H}), 4.41\left(\mathrm{~d}, 1 \mathrm{H}, J=15.6 \mathrm{~Hz},-\mathrm{CH}^{\prime}-\right)$, $4.47\left(\mathrm{~d}, 1 \mathrm{H}, J=15.6 \mathrm{~Hz},-\mathrm{CH}^{\prime \prime}-\right), 7.02(\mathrm{~d}, 2 \mathrm{H}, J=8.4 \mathrm{~Hz}, \mathrm{ArH}), 7.32-7.38(\mathrm{~m}, 3 \mathrm{H}, \mathrm{ArH}), 7.41-7.43(\mathrm{~m}, 2 \mathrm{H}$, ArH), 7.72-7.79 (m, 1H, ArH). HRMS calcd for $\mathrm{C}_{18} \mathrm{H}_{19} \mathrm{ClFN}_{3}(\mathrm{M}+\mathrm{H})^{+}, 332.1324$; found, 332.1321.

(E)-1-(4-Chlorophenyl)-N-((4-cyanophenyl)(piperazin-1-yl)methylene)methanamine hydrochloride (I-18): Yield 39\%, Mp: 180-182 ${ }^{\circ} \mathrm{C} .{ }^{1} \mathrm{H}-\mathrm{NMR}\left(400 \mathrm{MHz}, \mathrm{D}_{2} \mathrm{O}\right): \delta 3.35$ (br, $2 \mathrm{H}$, piperazinyl-H), $3.62(\mathrm{br}, 4 \mathrm{H}$, piperazinyl-H), $4.16\left(\mathrm{br}, 2 \mathrm{H}\right.$, piperazinyl-H), $4.37\left(\mathrm{~s}, 2 \mathrm{H},-\mathrm{CH}_{2}-\right), 7.01(\mathrm{~d}, 2 \mathrm{H}, J=8.4 \mathrm{~Hz}, \mathrm{ArH}), 7.34(\mathrm{~d}$, $2 \mathrm{H}, J=8.4 \mathrm{~Hz}, \mathrm{ArH}), 7.58(\mathrm{~d}, 2 \mathrm{H}, J=8.7 \mathrm{~Hz}, \mathrm{ArH}), 7.97(\mathrm{~d}, 2 \mathrm{H}, J=8.7 \mathrm{~Hz}, \mathrm{ArH})$. HRMS calcd for $\mathrm{C}_{19} \mathrm{H}_{19} \mathrm{ClN}_{4}(\mathrm{M}+\mathrm{H})^{+}$, 339.1371; found, 339.1368.

(E)-1-(4-Chlorophenyl)-N-((3-cyanophenyl)(piperazin-1-yl)methylene)methanamine hydrochloride (I-19): Yield 26\%, Mp: $156-158{ }^{\circ} \mathrm{C} .{ }^{1} \mathrm{H}-\mathrm{NMR}\left(400 \mathrm{MHz}, \mathrm{D}_{2} \mathrm{O}\right): \delta 3.21(\mathrm{br}, 2 \mathrm{H}$, piperazinyl-H), $3.49(\mathrm{br}, 4 \mathrm{H}$, piperazinyl-H), $4.03\left(\mathrm{br}, 2 \mathrm{H}\right.$, piperazinyl-H), $4.21\left(\mathrm{~d}, 1 \mathrm{H}, J=15.9 \mathrm{~Hz},-\mathrm{CH}^{\prime}-\right), 4.29(\mathrm{~d}, 1 \mathrm{H}, J=15.9 \mathrm{~Hz}$, $\left.-\mathrm{CH}^{\prime \prime}-\right), 6.85(\mathrm{~d}, 2 \mathrm{H}, J=8.7 \mathrm{~Hz}, \mathrm{ArH}), 7.21(\mathrm{~d}, 2 \mathrm{H}, J=8.7 \mathrm{~Hz}, \mathrm{ArH}), 7.56-7.67(\mathrm{~m}, 3 \mathrm{H}, \mathrm{ArH}), 7.93(\mathrm{~d}, 1 \mathrm{H}$, $J=7.8 \mathrm{~Hz}, \mathrm{ArH})$. HRMS calcd for $\mathrm{C}_{19} \mathrm{H}_{19} \mathrm{ClN}_{4}(\mathrm{M}+\mathrm{H})^{+}$, 339.1371; found, 339.1366 .

(E)-1-(4-Chlorophenyl)-N-(piperazin-1-yl(p-tolyl)methylene)methanamine hydrochloride (I-20): Yield 57\%, Mp: $183-185{ }^{\circ} \mathrm{C} .{ }^{1} \mathrm{H}-\mathrm{NMR}\left(400 \mathrm{MHz}, \mathrm{D}_{2} \mathrm{O}\right): \delta 2.41\left(\mathrm{~s}, 3 \mathrm{H},-\mathrm{CH}_{3}\right), 3.32(\mathrm{br}, 2 \mathrm{H}$, piperazinyl-H), $3.58(\mathrm{br}$, $2 \mathrm{H}$, piperazinyl-H), $3.63(\mathrm{br}, 2 \mathrm{H}$, piperazinyl-H), 4.11 (br, $2 \mathrm{H}$, piperazinyl- $\mathrm{H}), 4.40\left(\mathrm{~s}, 2 \mathrm{H},-\mathrm{CH}_{2}-\right)$, $7.04(\mathrm{~d}, 2 \mathrm{H}, J=8.1 \mathrm{~Hz}, \mathrm{ArH}), 7.27(\mathrm{~d}, 2 \mathrm{H}, J=8.4 \mathrm{~Hz}, \mathrm{ArH}), 7.35(\mathrm{~d}, 2 \mathrm{H}, J=8.4 \mathrm{~Hz}, \mathrm{ArH}), 7.43(\mathrm{~d}, 2 \mathrm{H}$, $J=8.1 \mathrm{~Hz}, \mathrm{ArH})$. HRMS calcd for $\mathrm{C}_{19} \mathrm{H}_{22} \mathrm{ClN}_{3}(\mathrm{M}+\mathrm{H})^{+}$, 328.1575; found, 328.1574 .

(E)-1-(4-Methoxyphenyl)-N-((4-nitrophenyl)(piperazin-1-yl)methylene)methanamine hydrochloride (I-21): Yield 15\%, Mp: $210-212{ }^{\circ} \mathrm{C} .{ }^{1} \mathrm{H}-\mathrm{NMR}\left(400 \mathrm{MHz}, \mathrm{D}_{2} \mathrm{O}\right): \delta 3.33$ (br, 2H, piperazinyl-H), 3.59 (br, 4H, piperazinyl-H), $3.81\left(\mathrm{~s}, 3 \mathrm{H},-\mathrm{OCH}_{3}\right), 4.15\left(\mathrm{br}, 2 \mathrm{H}\right.$, piperazinyl-H), $4.35\left(\mathrm{~s}, 2 \mathrm{H},-\mathrm{CH}_{2}-\right), 6.90(\mathrm{~d}, 2 \mathrm{H}$, $J=8.7 \mathrm{~Hz}, \mathrm{ArH}), 6.97(\mathrm{~d}, 2 \mathrm{H}, J=8.7 \mathrm{~Hz}, \mathrm{ArH}), 7.66(\mathrm{~d}, 2 \mathrm{H}, J=9.3 \mathrm{~Hz}, \mathrm{ArH}), 8.42(\mathrm{~d}, 2 \mathrm{H}, J=9.3 \mathrm{~Hz}$, ArH). HRMS calcd for $\mathrm{C}_{19} \mathrm{H}_{22} \mathrm{~N}_{4} \mathrm{O}_{3}(\mathrm{M}+\mathrm{H})^{+}, 355.1765$; found, 355.1766. 
(E)-1-(Naphthalen-1-yl)-N-(phenyl(piperazin-1-yl)methylene)methanamine hydrochloride (II-1): Yield 34\%, Mp: $187-189{ }^{\circ} \mathrm{C} .{ }^{1} \mathrm{H}-\mathrm{NMR}\left(400 \mathrm{MHz}, \mathrm{D}_{2} \mathrm{O}\right): \delta 3.33(\mathrm{t}, 2 \mathrm{H}, \mathrm{J}=5.4 \mathrm{~Hz}$, piperazinyl-H), 3.54-3.68 (m, 4H, piperazinyl-H), $4.12\left(\mathrm{t}, 2 \mathrm{H}, J=5.4 \mathrm{~Hz}\right.$, piperazinyl-H), $4.82\left(\mathrm{~s}, 2 \mathrm{H},-\mathrm{CH}_{2}-\right), 7.22(\mathrm{~d}, 1 \mathrm{H}, J=7.2 \mathrm{~Hz}, \mathrm{ArH})$, 7.40-7.44 (m, 3H, ArH), 7.51-7.57 (m, 4H, ArH), 7.60-7.68 (m, 2H, ArH), 7.87 (d, 1H, J = 8.1 Hz, ArH), $7.87\left(\mathrm{~d}, 1 \mathrm{H}, \mathrm{J}=9.0 \mathrm{~Hz}\right.$, ArH). HRMS calcd for $\mathrm{C}_{22} \mathrm{H}_{23} \mathrm{~N}_{3}(\mathrm{M}+\mathrm{H})^{+}, 330.1965$; found, 330.1962 .

(E)-1-(Naphthalen-1-yl)-N-((4-nitrophenyl)(piperazin-1-yl)methylene)methanamine hydrochloride (II-2): Yield 11\%, Mp: 202-204 ${ }^{\circ} \mathrm{C} .{ }^{1} \mathrm{H}-\mathrm{NMR}\left(400 \mathrm{MHz}, \mathrm{D}_{2} \mathrm{O}\right): \delta 3.34$ (br, 2H, piperazinyl-H), 3.60 (br, $4 \mathrm{H}$, piperazinyl-H), 4.21 (br, 2H, piperazinyl-H), $4.84\left(\mathrm{~s}, 2 \mathrm{H},-\mathrm{CH}_{2}-\right), 7.20(\mathrm{~d}, 1 \mathrm{H}, \mathrm{J}=6.9 \mathrm{~Hz}, \mathrm{ArH})$, 7.38-7.43 (m, 1H, ArH), 7.46-7.53 (m, 2H, ArH), 7.56-7.61 (m, 3H, ArH), 7.84-7.89 (m, 2H, ArH), 8.17 (d, $2 \mathrm{H}, \mathrm{J}=9.0 \mathrm{~Hz}, \mathrm{ArH})$. HRMS calcd for $\mathrm{C}_{22} \mathrm{H}_{22} \mathrm{~N}_{4} \mathrm{O}_{2}(\mathrm{M}+\mathrm{H})^{+}, 375.1816$; found, 375.1814 .

(E)-N-((4-Fluorophenyl)(piperazin-1-yl)methylene)-1-(naphthalen-1-yl)methanamine hydrochloride (II-3): Yield 24\%, Mp: $193-195{ }^{\circ} \mathrm{C} .{ }^{1} \mathrm{H}-\mathrm{NMR}\left(400 \mathrm{MHz}, \mathrm{D}_{2} \mathrm{O}\right): \delta 3.36$ (br, 2H, piperazinyl-H), $3.58(\mathrm{br}, 2 \mathrm{H}$, piperazinyl-H), $3.65(\mathrm{t}, 2 \mathrm{H}, J=4.2 \mathrm{~Hz}, J=5.7 \mathrm{~Hz}$, piperazinyl-H), $4.12(\mathrm{t}, 2 \mathrm{H}, J=5.1 \mathrm{~Hz}, J=5.4 \mathrm{~Hz}$, piperazinyl-H), 4.87 (s, 2H, - $\left.\mathrm{CH}_{2}-\right)$, 7.22-7.28 (m, 3H, ArH), 7.41-7.48 (m, 3H, ArH), 7.52-7.60 (m, 2H, ArH), 7.65-7.68 (m, 1H, ArH), $7.91(\mathrm{~d}, 1 \mathrm{H}, J=8.4 \mathrm{~Hz}, \mathrm{ArH}), 7.95-7.98(\mathrm{~m}, 1 \mathrm{H}, \mathrm{ArH})$. HRMS calcd for $\mathrm{C}_{22} \mathrm{H}_{22} \mathrm{FN}_{3}(\mathrm{M}+\mathrm{H})^{+}, 348.1871$; found, 348.1873 .

(E)-N-((2-Fluorophenyl)(piperazin-1-yl)methylene)-1-(naphthalen-1-yl)methanamine hydrochloride (II-4): Yield 41\%, Mp: $148-150{ }^{\circ} \mathrm{C} .{ }^{1} \mathrm{H}-\mathrm{NMR}\left(400 \mathrm{MHz}, \mathrm{D}_{2} \mathrm{O}\right): \delta 3.33$ (br, 2H, piperazinyl-H), $3.56(\mathrm{br}, 2 \mathrm{H}$, piperazinyl-H), 3.67 (br, 2H, piperazinyl-H), 4.12-4.21 (m, 2H, piperazinyl-H), $4.92\left(\mathrm{~s}, 2 \mathrm{H},-\mathrm{CH}_{2}-\right)$, 7.12 (br, 1H, ArH), 7.23-7.29 (m, 1H, ArH), 7.33-7.46 (m, 3H, ArH), 7.56 (br, 2H, ArH), 7.64-7.72 (m, $2 \mathrm{H}, \mathrm{ArH}), 7.88-8.05(\mathrm{~m}, 2 \mathrm{H}, \mathrm{ArH})$. HRMS calcd for $\mathrm{C}_{22} \mathrm{H}_{22} \mathrm{FN}_{3}(\mathrm{M}+\mathrm{H})^{+}, 348.1871$; found, 348.1868 .

(E)-N-((2-Chlorophenyl)(piperazin-1-yl)methylene)-1-(naphthalen-1-yl)methanamine hydrochloride (II-5): Yield 58\%, Mp: $165-167{ }^{\circ} \mathrm{C} .{ }^{1} \mathrm{H}-\mathrm{NMR}\left(400 \mathrm{MHz}, \mathrm{D}_{2} \mathrm{O}\right): \delta 3.34$ (br, 2H, piperazinyl-H), 3.63 (br, $4 \mathrm{H}$, piperazinyl-H), 4.15 (br, 2H, piperazinyl-H), 4.89 (s, 2H, $\left.-\mathrm{CH}_{2}-\right), 7.07$ (d, 1H, J = 6.6 Hz, ArH), 7.37-7.49 (m, 3H, ArH), 7.55-7.65 (m, 4H, ArH), 7.78-7.81 (m, 1H, ArH), 7.91 (d, 1H, J = 8.7 Hz, ArH), 7.98-8.04 (m, 1H, ArH). HRMS calcd for $\mathrm{C}_{22} \mathrm{H}_{22} \mathrm{ClN}_{3}(\mathrm{M}+\mathrm{H})^{+}, 364.1575$; found, 364.1574 .

(E)-N-((3-Chlorophenyl)(piperazin-1-yl)methylene)-1-(naphthalen-1-yl)methanamine hydrochloride (II-6): Yield 34\%, Mp: 198-200 ${ }^{\circ} \mathrm{C} .{ }^{1} \mathrm{H}-\mathrm{NMR}\left(400 \mathrm{MHz}, \mathrm{D}_{2} \mathrm{O}\right): \delta 3.31$ (br, 2H, piperazinyl-H), 3.65 (br,4H, piperazinyl-H), 4.12 (br, 2H, piperazinyl-H), $4.78\left(\mathrm{~s}, 2 \mathrm{H},-\mathrm{CH}_{2}-\right), 7.16(\mathrm{~d}, 1 \mathrm{H}, J=6.9 \mathrm{~Hz}, \mathrm{ArH})$, 7.29-7.32 (m, 2H, ArH), 7.39-7.62 (m, 6H, ArH), 7.87 (d, 1H, J = 8.4 Hz, ArH), 7.93 (d, 1H, J=6.9 Hz, ArH). HRMS calcd for $\mathrm{C}_{22} \mathrm{H}_{22} \mathrm{ClN}_{3}(\mathrm{M}+\mathrm{H})^{+}, 364.1575$; found, 364.1576.

(E)-N-((4-Chlorophenyl)(piperazin-1-yl)methylene)-1-(naphthalen-1-yl)methanamine hydrochloride (II-7): Yield 41\%, Mp: 210-212 ${ }^{\circ} \mathrm{C}$. ${ }^{1} \mathrm{H}-\mathrm{NMR}\left(400 \mathrm{MHz}, \mathrm{D}_{2} \mathrm{O}\right): \delta 3.19(\mathrm{t}, 2 \mathrm{H}, J=5.1 \mathrm{~Hz}, J=5.1 \mathrm{~Hz}$, piperazinyl-H), $3.43(\mathrm{t}, 2 \mathrm{H}, J=6.9 \mathrm{~Hz}, J=3.9 \mathrm{~Hz}$, piperazinyl- $\mathrm{H}), 3.50(\mathrm{t}, 2 \mathrm{H}, J=5.7 \mathrm{~Hz}$, piperazinyl-H), $4.12\left(\mathrm{t}, 2 \mathrm{H}, J=6.0 \mathrm{~Hz}\right.$, piperazinyl-H), $4.75\left(\mathrm{~s}, 2 \mathrm{H},-\mathrm{CH}_{2}-\right), 7.09(\mathrm{~d}, 1 \mathrm{H}, J=6.6 \mathrm{~Hz}, \mathrm{ArH}), 7.20(\mathrm{~d}$, $2 \mathrm{H}, J=8.4 \mathrm{~Hz}, \mathrm{ArH}), 7.30-7.35(\mathrm{~m}, 1 \mathrm{H}, \mathrm{ArH}), 7.38(\mathrm{~d}, 2 \mathrm{H}, J=8.4 \mathrm{~Hz}, \mathrm{ArH}), 7.41-7.54(\mathrm{~m}, 3 \mathrm{H}, \mathrm{ArH})$, 7.76-7.85 (m, 2H, ArH). HRMS calcd for $\mathrm{C}_{22} \mathrm{H}_{22} \mathrm{ClN}_{3}(\mathrm{M}+\mathrm{H})^{+}, 364.1575$; found, 364.1577.

(E)-4-(((Naphthalen-1-ylmethyl)imino)(piperazin-1-yl)methyl)benzonitrile hydrochloride (II-8): Yield 30\%, Mp: $158-160{ }^{\circ} \mathrm{C} .{ }^{1} \mathrm{H}-\mathrm{NMR}\left(400 \mathrm{MHz}, \mathrm{D}_{2} \mathrm{O}\right): \delta 3.34$ (br, 2H, piperazinyl-H), 3.63 (br,4H, piperazinyl-H), 4.18 (br, 2H, piperazinyl-H), $4.84\left(\mathrm{~s}, 2 \mathrm{H},-\mathrm{CH}_{2}-\right), 7.19(\mathrm{~d}, 1 \mathrm{H}, J=7.2 \mathrm{~Hz}, \mathrm{ArH}), 7.40-7.63(\mathrm{~m}, 6 \mathrm{H}, \mathrm{ArH})$, $7.77(\mathrm{~d}, 2 \mathrm{H}, J=8.4 \mathrm{~Hz}, \mathrm{ArH}), 7.88(\mathrm{~d}, 1 \mathrm{H}, J=8.1 \mathrm{~Hz}, \mathrm{ArH}), 7.94(\mathrm{~d}, 1 \mathrm{H}, J=9.0 \mathrm{~Hz}, \mathrm{ArH})$. HRMS calcd for $\mathrm{C}_{23} \mathrm{H}_{22} \mathrm{~N}_{4}(\mathrm{M}+\mathrm{H})^{+}$, 355.1917; found, 355.1921. 
(E)-3-(((Naphthalen-1-ylmethyl)imino)(piperazin-1-yl)methyl)benzonitrile hydrochloride (II-9): Yield 11\%, Mp: $168-170{ }^{\circ} \mathrm{C} .{ }^{1} \mathrm{H}-\mathrm{NMR}\left(400 \mathrm{MHz}, \mathrm{D}_{2} \mathrm{O}\right): \delta 3.16$ (br, 2H, piperazinyl-H), 3.45 (br,4H, piperazinyl-H), $4.04\left(\mathrm{br}, 2 \mathrm{H}\right.$, piperazinyl-H), $4.72\left(\mathrm{~d}, 1 \mathrm{H}, J=13.5 \mathrm{~Hz},-\mathrm{CH}^{\prime}-\right), 4.78\left(\mathrm{~d}, 1 \mathrm{H}, J=13.5 \mathrm{~Hz},-\mathrm{CH}^{\prime \prime}-\right), 6.85(\mathrm{~d}, 1 \mathrm{H}$, $J=5.7 \mathrm{~Hz}, \mathrm{ArH}), 7.01-7.05$ (m, 2H, ArH), 7.24-7.29 (m, 2H, ArH), 7.35-7.52 (m, 3H, ArH), 7.73-7.90 (m, $3 \mathrm{H}, \mathrm{ArH})$. HRMS calcd for $\mathrm{C}_{23} \mathrm{H}_{22} \mathrm{~N}_{4}(\mathrm{M}+\mathrm{H})^{+}$, 355.1917; found, 355.1911 .

(E)-1-(Naphthalen-1-yl)-N-(piperazin-1-yl(p-tolyl)methylene)methanamine hydrochloride (II-10): Yield 49\%, Mp: $178-180{ }^{\circ} \mathrm{C} .{ }^{1} \mathrm{H}-\mathrm{NMR}\left(400 \mathrm{MHz}, \mathrm{D}_{2} \mathrm{O}\right): \delta 2.38\left(\mathrm{~s}, 3 \mathrm{H},-\mathrm{CH}_{3}\right), 3.19(\mathrm{t}, 2 \mathrm{H}, J=5.4 \mathrm{~Hz}$, piperazinyl-H), $3.42(\mathrm{t}, 2 \mathrm{H}, \mathrm{J}=5.7 \mathrm{~Hz}$, piperazinyl-H), $3.51(\mathrm{t}, 2 \mathrm{H}, \mathrm{J}=5.4 \mathrm{~Hz}$, piperazinyl-H), $3.96(\mathrm{t}, 2 \mathrm{H}, J=5.4 \mathrm{~Hz}$, piperazinyl-H), 4.74 (s, 2H, $\left.-\mathrm{CH}_{2}-\right), 7.10-7.15(\mathrm{~m}, 3 \mathrm{H}, \mathrm{ArH}), 7.21$ (d, 2H, J = 8.1 Hz, ArH), 7.30-7.35 (m, 1H, ArH), 7.37-7.44 (m, 2H, ArH), 7.46-7.52 (m, 1H, ArH), 7.77 (d, 1H, J = 8.1 Hz, ArH), $7.83(\mathrm{~d}, 1 \mathrm{H}$, $J=9.3 \mathrm{~Hz}, \mathrm{ArH})$. HRMS calcd for $\mathrm{C}_{23} \mathrm{H}_{25} \mathrm{~N}_{3}(\mathrm{M}+\mathrm{H})^{+}, 344.2121$; found, 344.2108.

(E)-N-((5-Nitronaphthalen-1-yl)(piperazin-1-yl)methylene)-1-phenylmethanamine hydrochloride (III-1): Yield 14\%, Mp: 173-175 ${ }^{\circ} \mathrm{C}$. ${ }^{1} \mathrm{H}-\mathrm{NMR}\left(400 \mathrm{MHz}, \mathrm{D}_{2} \mathrm{O}\right): \delta 3.14-3.26(\mathrm{~m}, 2 \mathrm{H}$, piperazinyl-H), $3.51-3.57(\mathrm{~m}, 2 \mathrm{H}$, piperazinyl-H), $3.71(\mathrm{br}, 2 \mathrm{H}$, piperazinyl- $\mathrm{H}), 4.34(\mathrm{br}, 2 \mathrm{H}$, piperazinyl- $\mathrm{H}), 4.23(\mathrm{~d}$, $\left.1 \mathrm{H}, J=15.0 \mathrm{~Hz},-\mathrm{CH}^{\prime}-\right), 4.36\left(\mathrm{~d}, 1 \mathrm{H}, J=15.0 \mathrm{~Hz},-\mathrm{CH}^{\prime \prime}-\right), 6.73(\mathrm{~d}, 2 \mathrm{H}, J=6.6 \mathrm{~Hz}, \mathrm{ArH}), 7.06-7.16(\mathrm{~m}, 3 \mathrm{H}$, ArH), 7.59 (t, 1H, J = 7.8 Hz, ArH), 7.80-7.86 (m, 2H, ArH), $7.94(\mathrm{t}, 1 \mathrm{H}, J=7.2 \mathrm{~Hz}, \mathrm{ArH}), 7.29$ (d, 1H, $J=7.8 \mathrm{~Hz}, \mathrm{ArH}), 8.74(\mathrm{~d}, 1 \mathrm{H}, J=8.7 \mathrm{~Hz}, \mathrm{ArH})$. HRMS calcd for $\mathrm{C}_{22} \mathrm{H}_{22} \mathrm{~N}_{4} \mathrm{O}_{2}(\mathrm{M}+\mathrm{H})^{+}, 375.1816$; found, 375.1815 .

\subsection{Pharmacological Method}

\subsubsection{Inhibition of 5-HT or NE Reuptake Activity in Rat Brain Synaptosome}

All animal experiments were conducted in compliance with the Care and Use of Laboratory Animals, with the approval of Peking Union Medical College and Chinese Academy of Medical Sciences' Animal Studies Committee (Project code, 7102116; October 2010). Adult male Wistar rats were used. Animals were killed by decapitation and the whole brain, with the exception of the brainstem and cerebellum, was quickly removed. The procerebrum region was prepared, weighed, and homogenized in 10 volumes of ice-cold $0.32 \mathrm{~mol} / \mathrm{L}$ sucrose solution using a glass homogenizer. The homogenate was centrifuged at $1000 \times g$ and $4{ }^{\circ} \mathrm{C}$ for $10 \mathrm{~min}$. The supernatant was decanted and used for the uptake experiments. In the assay, the tissue suspension $(200 \mu \mathrm{L})$ was incubated with $50 \mathrm{nmol} / \mathrm{L}^{3} \mathrm{H}-\mathrm{NE}$ or $3 \mathrm{H}-5$-hydroxytryptamine $(800 \mu \mathrm{L})$ in Krebs-Henseleit bicarbonate buffer and a solution of the drug at the appropriate concentration $\left(20 \mu \mathrm{L} ; 1 \times 10^{-4}, 1 \times 10^{-5}, 1 \times 10^{-6}, 1 \times 10^{-7}\right.$, $\left.1 \times 10^{-8} \mathrm{~mol} / \mathrm{L}\right)$ or the vehicle $(20 \mu \mathrm{L})$ at $37^{\circ} \mathrm{C}$ for $10 \mathrm{~min}$. For each assay, three tubes were incubated with the vehicle $(20 \mu \mathrm{L})$ at $0{ }^{\circ} \mathrm{C}$ in an ice bath. After incubation, the tubes were immediately filtered with a cell harvester. The fiberglass filter membrane was washed three times with ice-cold saline, placed in a scintillation vial, and counted in liquid scintillation cocktail ( $4 \mathrm{~mL})$. Active uptake was the difference between the counts per minute at 37 and $0{ }^{\circ} \mathrm{C}$. The percent inhibition at each drug concentration was the mean of three measurements [15].

\subsubsection{TST in Rats}

Rats were administered the vehicle as a negative control, duloxetine $(30 \mathrm{mg} / \mathrm{kg})$ as a positive control, or test compounds I-19, II-4, and II-5 (30 mg/kg). For two days before the formal experiment, the rats in each group were given doses orally once a day in the morning and in the afternoon. The rats were given doses orally once in each group in the formal experiment. After 60 min of administration, the rats were suspended head-down more than $50 \mathrm{~cm}$ from the ground with a 12-cm-long piece of insulating tape at a distance of $1 \mathrm{~cm}$ from the tail tip. The distance between adjacent rats was $15 \mathrm{~cm}$. The immobility time of the rats was recorded. The rate of change in the immobility time of the rats in the test drug group and the positive control group was calculated and compared with the negative 
control group. Statistical analysis was performed using Prism 7.0 (GraphPad Software, San Diego, CA, USA). The data of the immobility time of vehicle, duloxetine, I-19, II-4, and II-5 were analyzed by the One-way ANOVA.

\subsubsection{Acute Toxicity Test}

Male ICR mice (20-25 g) were used from Institute of Materia Medica, Chinese Academy of Medical Sciences, Beijing, China. Mice were randomly divided into two groups with six mice each. Mice were orally given II-5 with a single dose 200 and $400 \mathrm{mg} / \mathrm{kg}$ or vehicle control, respectively. The mouse death was monitored for $20 \mathrm{~h}$ after treatment.

\section{Conclusions}

In this study, we designed and synthesized three series of arylamidine derivatives to discover potent reuptake inhibitors of 5-HT and NE transporters. Our results showed that series II compounds with a large aromatic ring exhibited improved in vitro 5-HT and NE inhibitory activity, and compound II-5 was the most potent dual inhibitor $\left(5-\mathrm{HT}, \mathrm{IC}_{50}=620 \mathrm{nM}\right.$; NE, $\left.\mathrm{IC}_{50}=10 \mathrm{nM}\right)$. Compounds I-19, II-4, and II-5 were selected for TST profiling in rats to test the in vivo antidepressant effect. These three compounds reduced the immobility time in the TST, indicating in vivo antidepressant activity. Compound II-5 showed the most potent in vivo antidepressant activity and had an acceptable safety profile. These arylamidine derivatives are interesting compounds to explore further as potential antidepressant drug candidates.

Author Contributions: H.W. and Y.G. conceived and wrote the paper; H.W., W.Q., and G.Y. performed the experiments and analyzed the data.

Funding: This work was financially supported by Beijing Natural Science Foundation of China (7102116).

Conflicts of Interest: The authors declare no conflict of interest.

\section{References}

1. Dilsaver, S.C.; Chen, Y.W.; Swann, A.C.; Shoaib, A.M.; Krajewski, K.J. Suicidality in patients with pure and depressive mania. Am. J. Psychiatry 1994, 151, 1312-1315. [CrossRef] [PubMed]

2. Schatzberg, A.F. New indications for antidepressants. J. Clin. Psychiatry 2000, 61 (Suppl. 11), 9-17. [PubMed]

3. Geneva. Depression Fact Sheet. Available online: http://www.who.int/mediacentre/factsheets/fs369/en/ (accessed on 29 May 2017).

4. Skolnick, P.; Popik, P.; Janowsky, A.; Beer, B.; Lippa, A.S. “Broad spectrum” anti-depressants: Is more better for the treatment of depression? Life Sci. 2003, 73, 3175-3179. [CrossRef] [PubMed]

5. Rakofsky, J.J.; Holtzheimer, P.E.; Nemeroff, C.B. Emerging targets for antidepressanttherapies. Curr. Opin. Chem. Biol. 2009, 13, 291-302. [CrossRef] [PubMed]

6. Wróbel, M.Z.; Chodkowski, A.; Herold, F.; Gomółka, A.; Kleps, J.; Mazurek, A.P.; Pluciński, F.; Mazurek, A.; Nowak, G.; Siwek, A.; et al. Synthesis and biologicalevaluation of novel pyrrolidine-2,5-dione derivatives as potential antide-pressant agents. Part 1. Eur. J. Med. Chem. 2013, 63, 484-500. [CrossRef] [PubMed]

7. Helguera, A.M.; Pérez-Garrido, A.; Gaspar, A.; Reis, J.; Cagide, F.; Vina, D.; Cordeiro, M.N.; Borges, F. Combining QSAR classification models for predictive modeling of human monoamine oxidase inhibitors. Eur. J. Med. Chem. 2013, 59, 75-90. [CrossRef] [PubMed]

8. Goodwin, G.M. How do antidepressants affect serotonin receptors? The role of serotonin receptors in the therapeutic and side effect profile of the SSRIs. J. Clin. Psychiatry 1996, 57 (Suppl. 4), 9-13. [PubMed]

9. Subbaiah, M.A.M. Triple Reuptake Inhibitors as Potential Therapeutics for Depressionand Other Disorders: Design Paradigm and DevelopmentalChallenges. J. Med. Chem. 2018, 61, 2133-2165. [CrossRef] [PubMed]

10. Shelton, R.C. The dual-action hypothesis: Does pharmacology matter? J. Clin. Psychiatry 2004, 65 (Suppl. 17), 5-10. [PubMed]

11. Qin, F.; Guo, Y.S.; Wen, H.; Yang, G.Z. Pharmacophore identification and comparison of serotonin/norepinephrine reuptake inhibitors. Acta Chim. Sin. 2009, 67, 2258-2268. 
12. Yang, J.; Wang, X.F.; Du, G.H.; Qin, F.; Wen, H.; Yang, G.Z. Design, synthesis and activity evaluation of novel selective serotonin reuptake inhibitors. Chem. J. Chin. Univ. 2007, 28, 1503-1507.

13. Yang, J.; Wang, X.F.; Wen, H.; Qin, F.; Yang, G.Z. Design, synthesis and in vitro evaluation of phenylbenzamidine derivatives as SSRIs. Chin. Chem. Lett. 2007, 18, 814-816. [CrossRef]

14. Qin, F.; Yang, J.; Wen, H.; Zhang, J.J.; Wang, Y.F.; Ji, C.X.; Yang, G.Z. Design, synthesis and 5-HT/NE dual reuptake inhibition activity of phenylbenzamidine derivatives. Chem. J. Chin. Univ. 2009, 30, 938-944.

15. Vogel, H.G.; Vogel, W.H.; Schölkens, B.A.; Sandow, J.; Müller, G.; Vogel, W.F. Drug Discovery and Evaluation-Pharmacological Assays, 2nd ed.; Springer: Berlin/Heidelberg, Germany, 2002; pp. 390-391. ISBN 978-35-4029-837-3.

Sample Availability: Samples of all compounds are available from the authors.

(C) 2019 by the authors. Licensee MDPI, Basel, Switzerland. This article is an open access article distributed under the terms and conditions of the Creative Commons Attribution (CC BY) license (http:/ / creativecommons.org/licenses/by/4.0/). 